\title{
A jóllét és a mentális egészség mérése: a Mentális Egészség Teszt
}

\author{
VARGHA ANDRÁS1,2* - ZÁBÓ VIRÁG ${ }^{1}-$ \\ TÖRÖK REGINA ${ }^{1}$ - OLÁH ATTILA² \\ ${ }^{1}$ Károli Gáspár Református Egyetem Bölcsészettudományi Kar \\ Pszichológiai Intézet, Budapest \\ ${ }^{2}$ ELTE Eötvös Loránd Tudományegyetem Pedagógiai és Pszichológiai Kar \\ Pszichológiai Intézet, Budapest
}

(Beérkezett: 2020. május 7.; elfogadva: 2020. július 14.)

Elméleti háttér: A mentális egészség egyfajta jóllét biológiai, pszichológiai, társadalmi és spirituális szinten, ezen kívül pedig képesség a pozitív állapotok fenntartására és megélésére, amelyhez a hatékony megküzdés és savoring, valamint a reziliencia és a dinamikus önszabályozás jelenléte is társul. A pozitív pszichológia egyik feladata, hogy érvényes teszteket dolgozzon ki a mentális egészség mérésére. Cél: A Mentális Egészség Teszt (MET) legújabb változatának átfogó pszichometriai ellenőrzése. Módszer: Két, online módon lefolytatott kérdőíves keresztmetszeti vizsgálat. I. 1540 fő (391 férfi, 1149 nő; átlagéletkor 52,0 év, SD = 11,3 év) demográfiai, valamint testi és lelki egészségre vonatkozó kérdések mellett kitöltötte az alábbi kérdőíveket: MET, PERMA Kérdőív, Globális Jóllét Kérdőív, Diener-féle Virágzás skála, Rövidített Savoring Hit Kérdőív, Rövidített Pszichológiai Immunrendszer Kérdőív. II. 1083 fó (233 férfi, 847 nő; átlagéletkor 33,9 év, SD = 12,2 év) demográfiai, a vallásosságra, valamint a testi és lelki egészségre vonatkozó kérdések mellett kitöltötte a MET, Aspirációs Index, Rövidített Beck Depresszió, WHO Jól-Lét, Élettel való Elégedettség, valamint Életcél Kérdőíveket. Eredmények: Az I. mintán elvégzett feltáró faktoranalízis megerősítette a MET ötfaktoros szerkezetét 17 tétellel, s az ezt tesztelő konfirmatív faktoranalízis jó illeszkedésú modellt jelzett. A II. mintában ugyanezen a faktorstruktúrán elvégzett konfirmatív faktoranalízis kiváló illeszkedésú (RMSEA $=0,051$; pClose $=0,408 ; \mathrm{CFI}=0,950$; TLI $=0,936)$. Az öt skála Cronbach- $\alpha$ értékei mindkét vizsgálatban 0,70 felettiek, magas belső konzisztenciát mutatva. A diszkriminációs validitást igazolja, hogy minden skálának van egy minimum $44 \%$-os olyan egyedi része, amelyet a többi négy skála nem fed le. A skálák tartalmi validitását a mentális egészség 10 tesztjével, speciális tesztkérdésekkel és szociodemográfiai mutatókkal sikerült igazolni. Fontos eredmény továbbá, hogy a jóllét pozitív irányú kapcsolatot mutat az anyagi helyzettel; az alkotó-végrehajtó hatékonyság a flow-val és az iskolázottsággal; az önreguláció és a reziliencia az életkorral; a savoring pedig a nóknél minden életkorban magasabb, mint a férfiaknál. Következtetés: a MET a jóllét, a savoring, az alkotó-végrehajtó hatékonyság, az önreguláció és a reziliencia konstruktumok megbízható és érvényes méróeszközének tekinthető.

Kulcsszavak: boldogságmérés, szubjektív jóllét, mentális egészség, Mentális Egészség Teszt, MET

* Levelező szerző: prof. Vargha András, Károli Gáspár Református Egyetem Bölcsészettudományi Kar Pszichológiai Intézet, 1024 Budapest, Keleti Károly u. 23. E-mail: vargha.andras@kre.hu 


\section{Bevezetés}

A pozitív pszichológia fokozott figyelmet fordít azoknak a személyen belüli forrásoknak és társas kapcsolatoknak a tanulmányozására, amelyek garanciái annak, hogy az emberek elégedettek legyenek a múltjukkal, boldogság és flow jellemezze a jelenüket, s reménnyel és optimizmussal nézzenek a jövőbe. A pozitív pszichológia egyik feladata az érvényes és megbízható tesztek kidolgozása a mentális egészség mérésére. A mentális egészség egyfajta jóllét biológiai, pszichológiai, társadalmi és spirituális szinten egyaránt, ezen kívül pedig képesség a pozitív állapotok fenntartására, megélésére, amelyhez a hatékony megküzdés és savoring, valamint a reziliencia és a dinamikus önszabályozás jelenléte is társul.

Felnőtt magyar populáción Oláh, Nagy, Magyaródi, Török és Vargha (2018) nevéhez fúződik egy új, a mentális egészséget mérő kérdőív, a Mentális Egészség Teszt (MET) kidolgozása. A MET a mentális egészség alábbi öt pillérének a mérésére lett megszerkesztve (Vargha, Török, Diósi, \& Oláh, 2019).

1. Jóllét (globális jóllét): az érzelmi, pszichológiai, szociális és spirituális téren egyaránt megtapasztalt jóllét (Oláh \& Kapitány-Fövény, 2012).

2. Savoring: a pozitív élmények átélésének, megteremtésének, fenntartásának, valamint fokozásának képessége (Bryant \& Veroff 2007; Szondy, Martos, Szabó-Bartha, \& Pünkösty, 2014). Azért használjuk az eredeti angol elnevezést, mert a tudomásunk szerint - egyelőre - nincs olyan magyar szó vagy rövid kifejezés, amely pontosan visszaadná ennek a pozitív pszichológiában használt igen fontos komplex fogalomnak a jelentését.

3. Alkotó-végrehajtó hatékonyság: olyan kompetencia, amellyel az egyén képes egy nehezített alkalmazkodási helyzet körülményeit megváltoztatni, eljutni a választott céljaihoz, továbbá az önmaga és a fizikai vagy szociális környezet megváltoztatására szőtt terveit szándékainak megfelelően megvalósítani (Oláh, 2005a).

4. Önreguláció: a figyelem és a tudati múködés feletti kontroll, célelérés során a perzisztencia, az érzelmi állapotok kontrollálása, és az önszabályozás képessége (Oláh, 2005a).

5. Reziliencia: lelki rugalmasság, pszichológiai ellenálló képesség (Block \& Kremen, 1996; Smith, Dalen, Wiggins, Tooley, Christopher, \& Bernard, 2008). A reziliencia elősegíti a stresszel teli helyzetekhez történő sikeres alkalmazkodást, a lelki mélypontokból, megrázkódtatásokból való gyors és hatékony felépülést (Campbell-Sills \& Stein, 2007; Connor \& Davidson, 2003; Southwick \& Charney, 2018).

Az erre az öt pillérre kialakított skáláival a MET konstruktuma itemanalízis és konfirmatív faktoranalízis (CFA) által igazoltan jó modellt alkot felnőtt (Oláh és mtsai, 2018), illetve 10-14 éves gyermek (Vargha és 
mtsai, 2019) magyar populációban, de a MET átfogó validitásvizsgálatára eddig még nem került sor. A jelen tanulmány célja a teszt reliabilitását és validitását igazoló új, nagy mintás vizsgálatok bemutatása, valamint ezek alapján a MET véglegesítése.

\section{Módszer}

\subsection{A Mentális Egészség Teszt (MET) skáláinak kialakítása}

A teszt alapkoncepciója, hogy egy rövid, 20 tételesnél nem hosszabb kérdőív segítségével átfogó képet nyerjünk a vizsgált személy mentális egészségéről a fentebb részletezett öt pillér vonatkozásában. Ha bármelyik skála tekintetében további tisztázandó kérdés merülne fel, célzott fókuszú speciális tesztek alkalmazása javasolt. Az öt skála tételei (skálánként 3-5 tétel) az alább részletezett megfontolások alapján kerültek kiválogatásra (Oláh és mtsai, 2018; Vargha és mtsai, 2019).

1. Jóllét: ez a skála a szubjektív jóllétet leginkább meghatározó három területről informál (Oláh és mtsai, 2018): (1) a pozitív-negatív élmények aránya (Fredrickson, 2009; vö. Függelék, 1. tétel); (2) a szubjektív lelki állapot minősége (Lyubomirsky, 2008; vö. Függelék, 14. tétel); illetve (3) a boldogság globális szintje (Huppert \& So, 2013; vö. Függelék, 18. tétel).

2. Savoring: e skála esetében a 10 tételes, 3 alskálás Rövidített Savoring Hit Kérdőív (Nagy, Magyaródi, Oláh, \& Vargha, 2019) tételeiből került három tétel kiválasztásra oly módon, hogy azok tartalmilag minél átfogóbbak, de formailag egyszerúek, érthetó megfogalmazásúak legyenek, továbbá e kérdőív összpontszámát magas szinten meghatározzák (Oláh és mtsai, 2018). A MET-be ezen alapelvek szerint beválasztott 3 tétel (vö. Függelék, 3., 10. és 12. tétele) változója többszörös lineáris regresszió elemzés alkalmazásával a 10 tételes Rövidített Savoring Hit Kérdőív összpontszámát $R^{2}=$ 0,814-es varianciaaránnyal magyarázta a Magyarország Boldogságtérképét elemző kutatás ${ }^{1} 2015-2019$ közötti adatai alapján, egy $n=8035$ fős részmintán.

3. Alkotó-végrehajtó hatékonyság: e skála a 16-tételes Rövidített Pszichológiai Immunrendszer Kérdőív (Rövidített PIK; Oláh, 2005b) azonos nevú skálájának 4 tételéból állt (Vargha és mtsai, 2019; vö. Függelék, 5., 7., 15. és 17. tétele), de ezt még kiegészítettük a teljes 80 kérdésból álló Pszichológiai Immunrendszer Kérdóív (Oláh, 2005a) egy olyan tételével, amelyet az alkotó-végrehajtó hatékonyság fontos összetevőjének gondoltunk (vö. Függelék, 9. tétel).

1 Vö. http://boldogsagprogram.hu/magyarorszag-boldogsagterkepe-2019/ 
4. Önreguláció: e skálához a 16 tételes Rövidített PIK (Oláh, 2005b) azonos nevú skálájának tételei (3 tételt) lettek kiválasztva (vö. Függelék, 2., 8. és 16. tétele) (Vargha és mtsai, 2019).

5. Reziliencia: e skálához a MET első változatában (Oláh és mtsai, 2018) szintén a Rövidített PIK (Oláh, 2005b) azonos nevú skálájának tételei lettek kiválasztva. Tekintettel azonban arra, hogy a rezilienciának számos különböző mérőskálája ismeretes (Block \& Kremen, 1996; Connor \& Davidson, 2003; Smith és mtsai, 2008; Windle, Bennett, \& Noyes, 2011), kerestünk közülük egy olyat, amely nemzetközi elismertségnek örvend, s amelyet már több nyelvre lefordítottak. E célnak megfelelt a Smith és munkatársai (2008) által szerkesztett 6-tételes Brief Resilience Scale. Ennek 4 könnyen érthető (2-2 pozitív, illetve negatív / fordított) tétele alapján a jelen cikk első és utolsó szerzője fogalmazta meg a skála tételeit a MET-ben (lásd Függelék 4., 6., 11. és 13. tétele). E 4 tétel változója többszörös lineáris regresszió elemzés alkalmazásával a 6-tételes teljes teszt összpontszámát $R^{2}=0,948$-es varianciaaránnyal magyarázta a Magyarország Boldogságtérképét elemző, fentebb említett kutatás adatai alapján, annak egy $n=475$ fós részmintáján.

A fenti megfontolások alapján a MET kérdőívébe a Függelékben látható 18 tétel került, skálánként rendre 3, 3, 5, 3, illetve 4 tétellel. Itt a tételek után látható, hogy melyik tétel melyik skálába tartozik. A válaszadás 6-fokú Likert-típusú skálán történik. A válaszlehetőségek végpontjai az első 17 tétel esetében 1 = egyáltalán nem jellemző és $6=$ teljes mértékben jellemző, míg a 18. tétel esetében $1=$ nagyon nem és $6=$ nagyon igen. A skálák közül a Jóllét, a Savoring, az Alkotó-végrehajtó hatékonyság csak pozitív, az Önreguláció pedig csak negatív formában megfogalmazott tételból áll. Végül a Reziliencia skálát 2-2 pozitív, illetve negatív tétel alkotja. A skálaképzés során a negatív irányban megfogalmazott tételek pontszámai megfordításra kerülnek, majd az adott skálákhoz tartozó tételeken elért pontszámok átlagolásával kapjuk meg a végső pontértékeket. A skálákon elért magasabb pontszám nagyobb mértékú jóllétet, savoringet, alkotó-végrehajtó hatékonyságot, önregulációt, illetve rezilienciát jelez.

\subsection{Vizsgálati terv}

A MET végleges változatának elkészítéséhez és validálásához a fentebb részletezett előkészületek után két vizsgálatot terveztünk. Az I. vizsgálat célja annak a tételegyüttesnek a kialakítása volt, amellyel a MET 5-dimenziós statisztikai modellje megfelelő illeszkedési mutatókat produkál, a II. vizsgálat fő célja pedig ennek megerősítése volt egy új, független minta segítségével. A szerkezeti validitás ilyetén igazolása után mindkét vizsgálatot felhasználtuk a MET tartalmi érvényességének teszteléséhez is. 


\subsection{A vizsgálatok bemutatása}

\subsubsection{Az I. vizsgálat}

\subsubsection{Résztvevők és eljárás}

A vizsgált személyek online felületen töltöttek ki egy 113 tételes kérdőívet, amelyet különböző életkorú, foglalkozású és érdeklődésú felnőtt személyek által gyakran látogatott Facebook-csoportokban (Szépkorúak csoportja, Mérnök szemmel, Jó szaki, Dunai horgászok, Budapesti fiatalok, Foci rajongók, Nekünk öröm a főzzés, Kertészkedők, Komolyzene-kedvelők és múvelők klubja, Szőlő Termelők és Borászok Klubja) tettünk közzé 2020 január közepétől két hónapig. A vizsgálat az ELTE PPK Pszichológiai Intézete Kutatásetikai Bizottságának engedélyével zajlott (az engedély száma: 2019/61) önkéntes és anonim módon, informált hozzájárulással, mindennemú kompenzáció nélkül.

Az érvényes vizsgálati mintát ${ }^{2} 1540$ magyarországi lakos (391 férfi és 1149 nő) alkotta. A mintába nem vettünk bele 196 külföldön élő ${ }^{3}$ személyt, akik a magyar nyelvú online kérdőívet kitöltötték és lakhelyüket az általuk megadott település neve alapján lehetett azonosítani. A minta szociodemográfiai jellemzőit az 1. táblázatban foglaltuk össze.

1. táblázat. Az I. vizsgálat résztvevőinek szociodemográfiai jellemzői ( $n=1540)$

\begin{tabular}{|c|c|c|c|c|c|}
\hline Életkor & $\begin{array}{c}\text { 18-25 éves: } \\
1,3 \%\end{array}$ & $\begin{array}{c}\text { 26-35 éves: } \\
5,6 \%\end{array}$ & $\begin{array}{c}\text { 36-50 éves: } \\
37,4 \%\end{array}$ & $\begin{array}{c}\text { 51-65 éves: } \\
43,5 \%\end{array}$ & $\begin{array}{c}\text { 66-90 éves: } \\
12,2 \%\end{array}$ \\
\hline $\begin{array}{l}\text { Gyermekek } \\
\text { száma }\end{array}$ & $\begin{array}{c}0: \\
16,7 \%\end{array}$ & $\begin{array}{c}1: \\
23,5 \%\end{array}$ & $\begin{array}{c}2: \\
42,0 \%\end{array}$ & $\begin{array}{c}3: \\
14,0 \%\end{array}$ & $\begin{array}{c}3+: \\
3,8 \%\end{array}$ \\
\hline Település & $\begin{array}{l}\text { község: } \\
\text { 21,3\% }\end{array}$ & $\begin{array}{c}\text { kisváros: } \\
33,2 \%\end{array}$ & $\begin{array}{c}\text { nagyváros: } \\
25,6 \%\end{array}$ & $\begin{array}{c}\text { föváros: } \\
\text { 19,9\% }\end{array}$ & \\
\hline $\begin{array}{l}\text { Iskolai } \\
\text { végzettség }\end{array}$ & $\begin{array}{c}\text { alapfok: } \\
1,7 \%\end{array}$ & $\begin{array}{c}\text { középfok: } \\
38,5 \%\end{array}$ & $\begin{array}{c}\text { főiskola: } \\
37,3 \%\end{array}$ & $\begin{array}{c}\text { egyetem: } \\
22,5 \%\end{array}$ & \\
\hline $\begin{array}{l}\text { Családi } \\
\text { állapot }\end{array}$ & $\begin{array}{c}\text { egyedül él: } \\
29,7 \%\end{array}$ & $\begin{array}{c}\text { élettársi } \\
\text { kapcsolatban: } \\
15,8 \%\end{array}$ & $\begin{array}{l}\text { házas: } \\
49,4 \%\end{array}$ & $\begin{array}{c}\text { özvegy: } \\
5,1 \%\end{array}$ & \\
\hline Foglalkozás & $\begin{array}{c}\text { alkalmazott: } \\
57,4 \%\end{array}$ & $\begin{array}{c}\text { nyugdíjas: } \\
22,0 \%\end{array}$ & $\begin{array}{c}\text { vállalkozó: } \\
\text { 14,5\% }\end{array}$ & $\begin{array}{c}\text { munkanélküli: } \\
3,5 \%\end{array}$ & $\begin{array}{l}\text { egyéb: } \\
2,6 \%\end{array}$ \\
\hline $\begin{array}{l}\text { Anyagi } \\
\text { helyzet }\end{array}$ & $\begin{array}{c}\text { szegény: } \\
2,1 \%\end{array}$ & $\begin{array}{c}\text { átlag alatti: } \\
5,5 \%\end{array}$ & $\begin{array}{c}\text { átlagos: } \\
75,4 \%\end{array}$ & $\begin{array}{c}\text { jómódú: } \\
\text { 16,4\% }\end{array}$ & $\begin{array}{c}\text { gazdag: } \\
0,6 \%\end{array}$ \\
\hline
\end{tabular}

\footnotetext{
2 Hozzáférhetőségi mintavétel.

3 Többségében romániai $(n=116)$ és szlovákiai $(n=22)$ lakosok.
} 
Az 1. táblázat adatai alapján megállapíthatjuk, hogy az I. vizsgálat mintája kellően heterogén ahhoz, hogy a minta alapján érvényes következtetéseket vonhassunk le a MET-tel kapcsolatban. Bár a minta többségét nők alkotják (74,6\%), a férfiak létszáma (391) is elég nagy ahhoz, hogy az eredmények általánosíthatósága ne csorbuljon lényegesen. Az életkort tekintve a személyek többsége (80,9\%) középkorú (36-65 éves), de a 65 év felettiek létszáma (188) is tekintélyes. Kirívó a 18-25 éves fiatalok igen alacsony aránya (1,3\%, 20 személy). A minta a településtípus szerint is kiegyenlített, a létszám minden kategóriában 300 feletti. A személyek több mint 98\%-a rendelkezik érettségivel, családi állapot szerint $65,2 \%$ párkapcsolatban él (49,4\% házasságban), az özvegyek aránya a legkisebb $(5,1 \%)$. A személyek többsége $(57,4 \%)$ alkalmazott (közülük 461 nem állami, 423 pedig állami, azaz közalkalmazott $\left.{ }^{4}\right)$, de számottevő a nyugdíjasok (22\%) és a vállalkozók (14,5\%) aránya is. A minta döntő többsége $(75,4 \%)$ anyagi helyzetét átlagosnak ítéli meg, de nem elhanyagolható a jómódú személyek aránya $(16,4 \%)$ sem. Alacsony azon válaszadók aránya, akik szegénynek $(2,1 \%)$ vagy gazdagnak $(0,6 \%)$ vallották magukat.

\subsubsection{Mérőeszközök}

A kérdőívból 9 kérdés a szociodemográfiai adatokra vonatkozott (nem, kor, lakhely stb., vö. 1. táblázat). Négy-négy egyedi, 6-fokú Likert-típusú skálán megválaszolandó kérdés a vizsgált személy testi és lelki állapotát (Testi és fizikai állapotom: 1 = egyáltalán nem megfelelő, 6 = teljes mértékben megfelelő; Általános lelki állapotom: 1 = egyáltalán nem megfelelő, 6 = teljes mértékben megfelelő; Elégedett vagyok az általános egészségi állapotommal: 1 = nagyon nem, 6 = nagyon igen; Fizikailag erősnek és szívósnak érzem magam: 1 = nagyon nem, 6 = nagyon igen), illetve az elmúlt időszakban megélt negatív élményeket mérte fel (Az utóbbi időben nagyon aggódom / nagyon ideges vagyok / nagyon feszültnek érzem magam / nagyon nyugtalanul alszom; a válaszlehetőségek végpontjai: 1 = nagyon nem jellemző, 6 = nagyon jellemző). 1 kérdés az aktuális boldogságra kérdezett rá rajzolt arcocskákkal, 7-fokú skálán (Jelölje be annak az arcocskának a betújelét, amelyik legjobban kifejezi azt, hogy mennyire boldog aktuálisan; a válaszlehetóségek végpontjai: 1 = legkevésbé boldog, 7 = lehetó legboldogabb).

Mentális Egészség Teszt (MET): a mérőeszköz részletes ismertetését ld. fentebb. Maga a kérdőív a Függelékben található.

Flow: Csíkszentmihályi flow konstruktumának kulcselemeit (beleolvadás a végzett tevékenységbe, kihívás-készség-egyensúly, folyamatosan fennálló

4 Hivatalosan közalkalmazott vagy köztisztviselő státuszban lévő. 
érdeklődés) Oláh (2005a, 2005b) alapján az alábbi 3 tétellel vizsgáltuk: Flow1. Ha valami igazán foglalkoztat, azt nehéz helyzetekben is képes vagyok élvezettel és elmélyülten csinálni; Flow2. Munkám teljesen leköti a figyelmemet; Flow3. Gyakran unatkozom (ez utóbbi tétel átfordítandó), amelyekre egy 6-fokú Likert-skálán lehetett válaszolni (a válaszlehetőségek végpontjai: 1 = nagyon nem jellemző, 6 = nagyon jellemző).

PERMA Kérdőív (PERMA-Profiler): A PERMA jólléti modellt Seligman (2018) fejlesztette ki, korábbi autentikus boldogság koncepciójának továbbépítésével. Seligman 2.0-ás modellje szerint a jóllét elméletnek öt pillére van, ezek: a pozitív érzelem (positive emotion: P), az elmélyülés (engagement: E), a pozitív kapcsolatok (positive relationship: R), az értelem (meaning: M) és a teljesítmény öröme (accomplishment: A). Ezek emlékezeterősítő rövidítése a PERMA. Az öt pillért hangsúlyozó modell komponensei egymást erősítve járulnak hozzá a jóllét állapotának a megteremtéséhez és fenntartásához. Seligman modelljének mérésére Butler és Kern (2016) szerkesztette meg a PERMA-Profiler elnevezésú, 23 tételből álló kérdőívet. Mindegyik tételhez egy 11 fokú, $0-10$-ig terjedő Likert-skála tartozik $(0=$ soha / egyáltalán nem / rettenetesen rossz; 10 = mindig / teljes mértékben / kiváló), amelyen a kitöltó jelölheti, hogy saját meglátása szerint az adott tétel milyen mértékben vonatkozik rá / jellemző az életében. A 23 tételből 15 az 5 alappillért méri 3-3 tétellel, a további 8 tételból 3-3 a negatív érzelmeket (pl. Milyen gyakran szorong?), és az egészséget (pl. Általánosságban hogyan jellemezné egészségi állapotát?), végül 1-1 tétel a boldogságot (Mindent egybevetve mennyire érzi boldognak magát?) és a magányosságot (Mennyire érzi magányosnak magát a mindennapjaiban?) méri. Az alappilléreket képviselő skálák közül a Pozitív érzelem skála a pozitív érzelmek megélésének gyakoriságára fókuszál (pl. Milyen gyakran érzi magát vidámnak?). Az Elmélyülés skála a flow élmény átélésének gyakoriságát, a kognitív és érzelmi források koncentrált lekötésének képességét méri (pl. Milyen gyakran feledkezik bele abba, amit csinál?). Az Értelem skála az értelmes célok kitúzésének, az értelemkeresésnek és az értelmes, önmagunkat meghaladó célok szolgálatának tendenciáit vizsgálja (Milyen mértékben érzi, hogy értékes és értelmes életet él?). A Teljesítmény skála arról informál, hogy a saját teljesítménnyel elérhető siker, a kompetencia megélésének öröme milyen mértékben járul hozzá a jóllét növeléséhez a vizsgált személy életében (pl. Milyen gyakran sikerül elérni azokat a fontos célokat, melyeket önmagának túzött ki?). A Pozitív kapcsolatok skála pedig azt méri, hogy milyen mértékben igaz az egyén életére, hogy a boldogság, a szeretet a másokhoz kötődő jó viszony a jóllét sine qua non-ja (pl. Milyen mértékben érzi azt, hogy szeretik?).

A PERMA Kérdőív magyar változatának a szerzők által engedélyezett elkészítése az oda- és visszafordítás elvárásait követő adaptálással Oláh 
(2016) nevéhez fúződik. Jelen vizsgálatunkban a PERMA Kérdőív minden skálája megbízhatónak mutatkozott a következő Cronbach- $\alpha$ értékekkel: Pozitív érzelmek: 0,883; Elmélyülés: 0,558; Pozitív kapcsolatok: 0,791; Értelem: 0,762; Teljesítmény: 0,738; Egészség: 0,879; Negatív érzelem: 0,771.

Globális Jóllét Kérdőiv: Érzelmi, Pszichológiai, Szociális és Spirituális jóllét skálájával ez a kérdóív a jóllét bio-pszicho-szocio-spirituo modelljét operacionalizálja, hangsúlyozva, hogy a teljes jóllét feltétele, hogy az ember humán természetének minden aspektusában jól múködjön, miközben jól érzi magát a bőrében. A Globális jóllét modell Diener szubjektív jóllét, Ryff pszichológiai jóllét és Keyes szociális jóllét konstruktumát integrálja, kiegészítve ezeket a spirituális jóllét konstruktumával. A kérdőív 17 tételére a válaszok 6-fokú Likert-skálán adhatók meg (végpontok: 1 = egyáltalán nem jellemző, 6 = teljes mértékben jellemző). Az 5 tételból álló Érzelmi jóllét skála az élettel való elégedettséget, a pozitív érzelmek dominanciáját és a pozitív orientációt méri ( $\mathrm{pl}$. Az én mindennapjaimban legalább háromszor vagy még többször több az öröm, mint a bánat). A 4 tételt tartalmazó Pszichológiai jóllét skála a pszichológiai jól múködés feltételeit: az autonómiát, a környezet uralását, az önmagunkkal és a másokkal való jó viszonyt, a folyamatos fejlődés élményét az értelmes célok követésének és keresésének a tendenciáit méri fel ( $\mathrm{pl}$. Az életem tele van értelmes célokkal). A Szociális jóllét skála a társas kapcsolatok harmonikus kialakításának és a társas világba való integrálódás képességét, illetve a társas világ összefüggésrendszerének megértésére való képességet teszteli (pl. Sok olyan közösséghez tartozom, ahol jól érzem magam és ahol szívesen fogadnak). A Spirituális Jóllét Skála 4 tétele a vertikális és horizontális felelősségtudat mértékét, az önmagunkat meghaladás képességét, a spirituális élmények keresését és azok örömforrásként való megélésének képességét vizsgálja (pl. Az érzés, hogy része lehetek az emberiség jövőjéért felelősséget viselők nagy közösségének, boldogsággal tölt el).

A kérdőív dimenzionális szerkezetét és ezzel együtt a Globális Jóllét négypilléres konstruktumát egy magyar felnőtt mintától (12378 férfi és nő, átlagéletkor: 44,4 [SD=14,5] év) interneten felvett kérdőív válaszok elemzése alapján konfirmatív faktorelemzés (CFA) igazolta (SRMR =0,038; RMSEA = 0,064; RMSEA CI90: 0,063-0,066; CFI = 0,949; TLI = 0,936) (Oláh és mtsai, 2020). A skálák megbízhatóságát magas Cronbach- $\alpha$ értékek igazolták (Oláh, 2016). Jelen kutatásban az egyes skálák Cronbach- $\alpha$ értékei a következők: Érzelmi jóllét: 0,923; Pszichológiai jóllét: 0,883; Szociális jóllét: 0,892; Spirituális jóllét: 0,906.

Diener-féle Virágzás Skála (Diener és mtsai, 2009): a 8 tételes skála Diener szubjektív jóllét koncepciójának továbbfejlesztett változatát operacionalizálja, amelyben az élettel való megelégedettség és a pozitív érzelmek dominanciája mellett kiegészítésként megjelenik a kompetencia, az optimiz- 
mus, a mások jóllétéhez való hozzájárulás, az életcél, az önbecsülés és a pozitív kapcsolatok szükségességének hangsúlyozása. A tételek (pl. Céltudatos és értelmes életem van) értékelése 7-fokú (a válaszlehetőségek végpontjai: 1 = egyáltalán nem jellemző, 7 = teljes mértékben jellemző). A kérdőívet Görgényi Judit fordításának felhasználásával választottuk vizsgálataink egyik mérőeszközeként. A skála számos nemzetközi közlemény szerint megbízhatóan méri a jóllét komponenseit. Jelen vizsgálatunkban a skála Cronbach- $\alpha$ értéke 0,938 volt.

Röviditett Savoring Hit Kérdőív: Bryent és Veroff (2007) a pozitív élmények elérését, fenntartását és fokozását elősegítő technikák vizsgálatára szerkesztette a 24 tételes Savoring Belief Inventory-t, amelynek hazai adaptálását és 10 tételes rövidített változatának elkészítését Nagy és munkatársai (2019) végezték el. A tételeket (pl. Képes vagyok már előre élvezni az eseményeket gondolatban, mielőtt azok megtörténnének) 7-fokú Likert-skálán kell megválaszolni (a válaszlehetőségek végpontjai: 1 = egyáltalán nem jellemző rám, $7=$ teljes mértékben jellemző rám). A 10 tételes változat 0,890 -es korrelációt mutatott az eredeti kérdőívvel. A kérdőív 3 tételes Savoring Múlt skálája azokat a stratégiákat azonosítja, amelyek segítségével a múlt emlékeinek a jelenbe hozásával változtathatjuk pozitív irányba aktuális érzelmi állapotunkat. A szintén 3 tételes Savoring Jelen skála olyan technikákra fókuszál, amelyek alkalmazásával az aktuálisan átélt pozitív érzelmet meghosszabbíthatjuk, élénkebbé tehetjük. Végül a 4 tételes Savoring Jövő skála a rövidesen elérhető vagy a jövőben megvalósuló pozitív élmények anticipálására koncentrál. A savoring mechanizmusok ezen három változatát mérő és az eredeti modellt operacionalizáló 10 tételes és 3 skálás kérdőív pszichometriailag megfelelő voltát Nagy és munkatársai (2019) itemanalízissel és konfirmatív faktoranalízissel igazolták. Három vizsgálatban, öszszesen közel 10000 fő adatait elemezve a 10 tételes kérdőív három faktorra bontható szerkezetét a konfirmatív faktoranalízis elfogadható illeszkedési mutatókkal igazolta (RMSEA: 0,049-0,060; CFI: 0,958-0,976; TLI: 0,9400,967; SRMR: 0,021-0,030). A skálák belső konzisztenciáját becslő 0,772 és 0,931 közötti Cronbach- $\alpha$ mutatók is megerősítették a skálák megbízhatóságát. Jelen vizsgálatunkban a skálák Cronbach- $\alpha$ értékei hasonló szintúek voltak, a következő értékekkel: Savoring Múlt: 0,850; Savoring Jelen: 0,848; Savoring Jövő: 0,896.

Rövidített Pszichológiai Immunrendszer Kérdőív (Rövidített PIK): A Rövidített PIK a 80 tételból, álló 16 skálát tartalmazó Pszichológiai Immunrendszer Kérdőív (PIK, vö. Oláh, 2005a) 16 tételes rövidített változata. A rövidítés során a hosszú változatból a 16 skálát prototípusosan képviselő egy-egy tétel került a rövid tesztbe és ennek a 16 tételnek a feltáró faktoranalízise 4 független, a pszichometriai elemzések eredményei szerint önálló skálaként is megbízhatóan viselkedő faktort eredményezett. A kérdőív tételeire 
4-fokozatú Likert-típusú skálán lehet válaszolni (végpontok: 1 = egyáltalán nem jellemző, 4 = teljes mértékben jellemző). A Rövidített PIK négy skálája, a Megközelítő-monitorozó viselkedés (MMV), Alkotó-végrehajtó viselkedés (AVV), Önreguláció (ÖR) és Reziliencia (R) a megküzdési eredményességet szavatoló coping vonásokat, pszichológiai antitesteket azonosítja, s elméleti háttere és mérési tartománya megegyezik az eredeti változatéval. A pszichológiai immunmúködés elméleti modellje szerint a változásokhoz éber alakító magatartással viszonyuló (MMV), pszichológiai tőkéjét és alkalmazkodási forrásait problémafókuszúan és alkotó módon mobilizáló (AVV), differenciált eszközrendszerrel operáló önregulációval (ÖR) és dinamikus, reziliens önszabályozással (R) jellemezhető múködés vezet folyamatos fejlődést és egészségfenntartást eredményező megküzdéshez. A Rövidített PIK kérdőív dimenzionális szerkezetét és az elméleti hátterét adó pszichológiai immunitás modell konstruktum érvényességét egy 7863 fős felnőtt mintától származó, interneten felvett Rövidített PIK válaszokon végzett konfirmatív faktoranalízis igazolta (RMSEA: 0,059; CFI: 0,936; TLI: 0,920; SRMR: 0,042) (Oláh és mtsai, 2020). A jelen vizsgálatban a Rövidített PIK négy skálájának Cronbach- $\alpha$ értékei (MMV: 0,832; AVV: 0,786; ÖR: 0,817; R: 0,777) azt mutatják, hogy a Rövidített PIK a jelen vizsgálatunkban is megbízhatóan mért.

Megnyugtató, hogy egyetlen kivétellel (a PERMA Kérdőív Elmélyülés alskálája) a fenti tesztek skálái mind kiváló reliabilitásúak voltak, 0,73 feletti Cronbach- $\alpha$ értékkel.

\subsubsection{A II. vizsgálat}

\subsubsection{Résztvevők és eljárás}

A vizsgált személyek online felületen töltöttek ki egy 179 tételes kérdőívet. A kérdőívet a leggyakrabban használt közösségi oldal, a Facebook különböző csoportjaiban tettük közzé. Terület (pl. II. kerületben élők, „Sopronban láttam”, „Debrecenben hallottam”), egy-egy téma (pl. természetvédők, vegetáriánusok), sport (pl. kajak-kenu, edzéstervek-tapasztalatok, kezdő futók), foglalkozás (pl. álláskeresők csoportja, szociális gondozók), vallásosság (pl. ateista-keresztény vitacsoport, keresztény fiatalok, keresztény idézetek, keresztények párbeszéde csoport), felsóoktatás (pl. joghallgatók, tanító szakosok) és egyéb (pl. matematika mindenkinek, motivációk mindennapra) szerint rendeződő csoportokból vártuk a válaszokat, hogy a vizsgált személyek minél több társadalmi rétegból kerüljenek ki. A II. vizsgálat a KRE Pszichológiai Intézete Kutatásetikai Bizottságának engedélyével zajlott (az engedély száma: 70/2019/P/ET/2) önkéntes és anonim módon, informált hozzájárulással, mindennemú kompenzáció nélkül. 
Az érvényes vizsgálati mintát ${ }^{5} 1083$ személy alkotta (233 férfi, 847 nő; 3 személy nem adta meg a nemét), akik online felületen töltötték ki a 179 tételes kérdőívet 2019 decembere és 2020 márciusa között. Szociodemográfiai jellemzőiket a 2. táblázatban foglaltuk össze.

\begin{tabular}{|c|c|c|c|c|c|c|c|}
\hline & 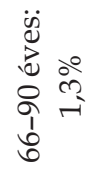 & & 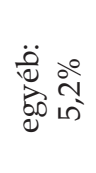 & & & & \\
\hline & 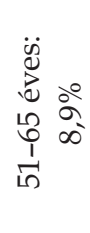 & 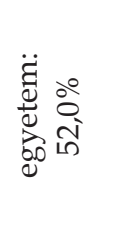 & 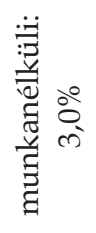 & & & & 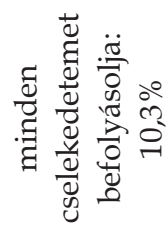 \\
\hline 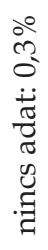 & 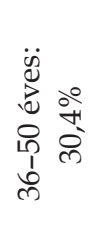 & 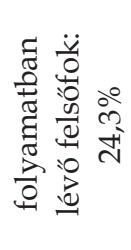 & 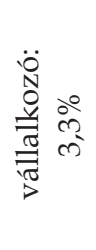 & 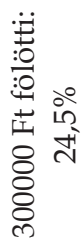 & 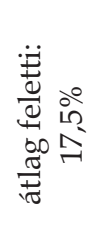 & 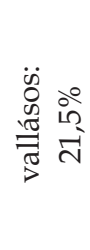 & 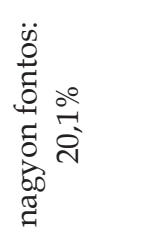 \\
\hline $\begin{array}{l}\stackrel{\circ}{N} \\
\infty \\
\\
\ddot{0} \\
0\end{array}$ & 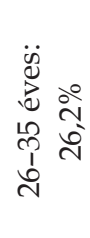 & 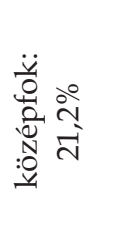 & 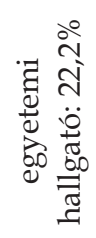 & 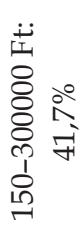 & 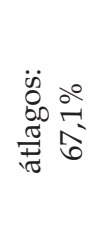 & 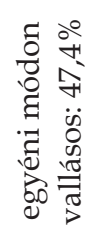 & 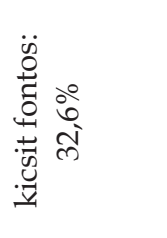 \\
\hline 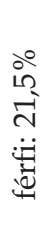 & 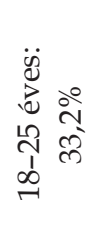 & 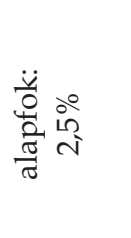 & 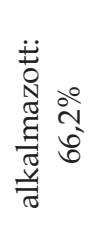 & 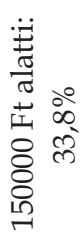 & 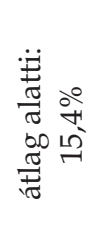 & 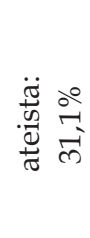 & 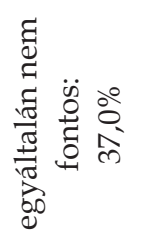 \\
\hline$\stackrel{\Xi}{Z}$ & 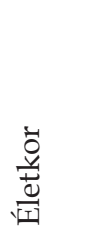 & 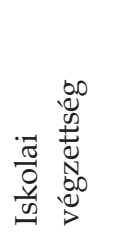 & 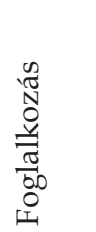 & 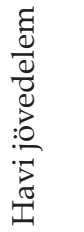 & 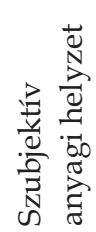 & 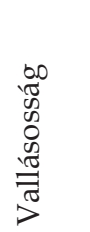 & 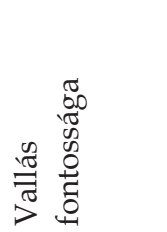 \\
\hline
\end{tabular}

5 Hozzáférhetőségi mintavétel. 
A 2. táblázat adatai alapján megállapíthatjuk, hogy a II. vizsgálat mintája valamivel kevésbé heterogén és összetételében kissé más, mint az I. vizsgálaté. A minta többségét itt is a nők alkotják $(78,2 \%)$. Lényegesen több viszont itt a legfeljebb 25 éves fiatal (33,1\% vs. $2 \%)$ és lényegesen kisebb az 50 évesnél idősebbek aránya (10,2\% vs. 52,7\%). Ezzel összefüggésben több az egyetemi hallgató $(22,2 \%)$ és kevesebb a nyugdíjas (1,4\%, az egyéb kategória részeként). A minta döntő többsége $(67,1 \%)$ az anyagi helyzetét itt is átlagosnak ítéli meg. A vallásosság tekintetében $68,9 \%$-a vallja magát valamilyen módon vallásosnak és 31,1\%-a ateistának, ugyanakkor 30,4\% nyilatkozik úgy, hogy számára a vallásosság fontos (vagy nagyon fontos).

\subsubsection{Mérőeszközök}

A kérdőívből 8 kérdés a szociodemográfiai adatokra vonatkozott (nem, kor stb., vö. 2. táblázat), 3 egyedi kérdés a vizsgált személy testi és lelki jóllétére vonatkozott: (1) Szubjektív egészségi állapot = „Összességében hogyan minősítené saját egészségi állapotát?" (válaszlehetőségek: 1 = nagyon rossz, 2 = rossz, 3 = közepes, 4 = jó, 5 = kiváló); (2) Szubjektív elégedettség = „Egészében véve mostanában mennyire elégedett az életével?" (a válaszlehetőségek végpontjai: 1 = teljesen elégedetlen, 10 = teljesen elégedett); (3) Szubjektív boldogság $=$ „Egészében véve mennyire tartja boldognak saját magát?" (a válaszlehetőségek végpontjai: $1=$ teljesen boldogtalan, $10=$ teljesen boldog).

Mentális Egészség Teszt (MET): a mérőeszköz részletes ismertetését ld. fentebb, illetve a Függelékben. Ezúttal azonban a MET-et kiegészítettük két további tétellel. Ezek egyike a személy flow átélő képességét firtatta ${ }^{6}$. Validációs célból betettük még a Rövidített Beck Depresszió Kérdőív 4. tételét $^{7}$, azonban nem 4 , hanem 6 válaszlehetőséggel (végpontok: 1 = egyáltalán nem jellemző, 6 = teljes mértékben jellemző).

Az Aspirációs Index röviditett, 14 tételes változata: a Kasser és Ryan-féle Aspirációs Index (Kasser \& Ryan, 1996; Aspiration Index) a hosszú távú általános célok feltárására szolgál, amelyek az intrinzik (tartalmas emberi kapcsolatok, személyes növekedés, közösség iránti elkötelezettség), az extrinzik (gazdagság, hírnév, jó megjelenés) és az egészség kategóriákba sorolhatók. A rövidített változat (Martos, Szabó, \& Rózsa, 2006) 14 tételt tartalmaz, a kapcsolatok mérésére például az „Érezzem, hogy vannak emberek, akik szeretnek, és viszont szeretem őket” tétel, a közösség iránti elkötelezettség vizsgálatára a "Munkámmal is hozzájáruljak, hogy a világ jobb legyen”

6 Ugyanaz, mint az I. vizsgálat Flow1 tétele: „Ha valami igazán foglalkoztat, azt nehéz helyzetekben is képes vagyok élvezettel és elmélyülten csinálni."

7 „Túlságosan fáradt vagyok ahhoz, hogy bármit is csináljak." 
tétel szolgál. A tételek megítélése hétfokú Likert-skálán történik (a válaszlehetőségek végpontjai: 1 = egyáltalán nem értek egyet, 7 = teljesen egyetértek). Az Aspirációs Indexnek 3 alskálája van (extrinzik, intrinzik és egészség aspirációkra vonatkozó alskálák). Minél magasabb a skálákon elért pontszám, annál fontosabbak a személy számára a skálák által mért célok. Jelen vizsgálatban a következő Cronbach- $\alpha$ értékeket kaptuk: Intrinzik aspirációk: 0,741; Extrinzik aspirációk: 0,797; Egészség aspirációk: 0,549.

Röviditett Beck Depresszió Kérdőiv: A 9 tételes mérőeszköz (Beck, Guth, Steer, \& Ball, 1997; magyar változat: Rózsa, Szádóczky, \& Füredi, 2001) 4-fokú Likert-skálán (végpontok: 1 = egyáltalán nem jellemző, 4 = teljesen jellemző) 9 tétellel kérdez rá a depresszió alábbi tüneteire: szociális visszahúzódás, döntésképtelenség, alvászavar, fáradékonyság, túlzott aggódás a testi tünetek miatt, munkaképtelenség, pesszimizmus, elégedettség és öröm hiánya, valamint önvádlás. A testi tünetek miatti túlzott aggódás például ezzel a kérdéssel mérhetó: „Annyira aggódom a testi-fizikai panaszok miatt, hogy másra nem tudok gondolni." A magasabb pontszámok több depreszsziós tünetre utalnak. Jelen vizsgálatban a Cronbach- $\alpha$ értéke 0,859.

A WHO Jól-Lét Kérdôív rövidített változata: Az 5-tételes skála (Bech, StaehrJohansen, \& Gudex, 1996; magyar változat: Susánszky, Konkolÿ Thege, Stauder, \& Kopp, 2006) a vizsgált személy általános közérzetéről kíván információt nyújtani a vizsgálatot megelőző kéthetes időszak alapján az alábbi 5 kérdéssel, azokat 4-fokú Likert-skálán (a válaszlehetőségek végpontjai: 1 = egyáltalán nem jellemző, $4=$ teljesen jellemző ${ }^{8}$ ) értékelve: Az elmúlt két hét során érezte-e magát vidámnak és jókedvúnek? / ... nyugodtnak és ellazultnak? / ... aktívnak és élénknek? / ... ébredéskor frissnek és élénknek? / ... a napjai tele voltak számára érdekes dolgokkal? A skálán elért magasabb pontszám jobb, pozitívabb közérzetet jelez. Jelen vizsgálatban a Cronbach- $\alpha$ értéke 0,872 .

Élettel való Elégedettség Skála: Az 5 tételes méróeszköz (Diener, Emmons, Larsen, \& Griffin, 1985; magyar változat: Martos, Sallay, Désfalvi, Szabó, \& Ittzés, 2014) az élettel való globális elégedettséget méri. A tételek (például „Az életem a legtöbb tekintetben közel van az ideálishoz" vagy „Ha újra leélhetném az életem, szinte semmin sem változtatnék") értékelése 7-fokú Likert-skálán történik (a válaszlehetőségek végpontjai: 1 = egyáltalán nem értek egyet, 7 = teljes mértékben egyetértek). A skálán elért magasabb pontszám nagyobb mértékú élettel való elégedettséget jelez. Jelen vizsgálatban a Cronbach- $\alpha$ értéke 0,873.

\footnotetext{
8 A kérdőív tételei eredetileg a 0-3 skálán mérnek. Mi azért tértünk át az 1-4 skálára, mert kérdőívünk összes tételénél 1 volt a lehetséges legkisebb érték. Ugyanakkor az értékek alatt itt is mindenütt megjelentek az eredeti válaszlehetőségek (úgymint egyáltalán nem jellemző, alig jellemző, jellemző, teljesen jellemző).
} 
Életcél Kérdőiv: Az élet értelmességét mérő 20-tételes kérdőív (Purpose in Life Test, Crumbaugh és Maholick, 1964; magyar változat: Konkolÿ Thege és Martos, 2006) a Viktor Frankl által megfogalmazott értelmesség konstruktum egészét kívánja mérni - noha neve pusztán a célokat hangsúlyozza. Tételei közé tartozik például: „Ha a világhoz fúződő viszonyomat nézem, a világ ... zavaros és érthetetlen számomra / értelmes összhangban van az életemmel” vagy "Ha az életemre gondolok, ... gyakran túnődök azon, hogy egyáltalán miért is élek / mindig látom, hogy miért vagyok a világon". A skála tételeit 7-fokú Likert-skálán értékelik a kitöltők (a válaszlehetőségek végpontjai: 1 = egyáltalán nem értek egyet, 7 = teljesen egyetértek). Minél magasabb a skálán elért pontszám, annál több vonatkozásban érzi a vizsgált személy értelmesnek az életét. Jelen vizsgálatban a Cronbach- $\alpha$ értéke 0,842.

A Young-féle Séma Kérdöív rövidített, 95 tételes változata. A 195-tételes séma alskála öt sématartományba rendeződik: 1. Elszakítottság és elutasítás (pl. Érzelmi depriváció-érzelemmegvonás séma, Elhagyatottság-instabilitás séma), 2. Károsodott autonómia és teljesítőképesség (pl. Kudarcra ítéltség séma, Dependencia-inkompetencia séma), 3. Károsodott határok (Feljogosítottság-grandiozitás séma, Elégtelen önkontroll-önfegyelem séma), 4. Kóros másokra irányultság sématartomány (pl. Önfeláldozás séma, Elismeréshajszolás séma) és 5. Aggályosság és gátlás (Negativizmus-pesszimizmus séma, Érzelmi gátoltság séma). Az Elhagyatottság-instabilitás sémába tartozik például a „Kétségbe esek, mikor azt érzem, hogy egy szeretett személy kezd eltávolodni tőlem" tétel, az Önfeláldozás séma egyik tétele pedig a „Legtöbbször végül én vagyok az, aki gondoskodik a hozzám közel állókról". A 19 alskála Cronbach- $\alpha$ értékei vizsgálatunkban 0,762 és 0,940 közé estek.

Megnyugtató, hogy a fenti tesztek, illetve alskáláik egyetlen kivétellel (Aspirációs Index 2 tételes Egészség aspirációk alskálája) mind kiváló reliabilitásúak voltak, 0,74 feletti Cronbach- $\alpha$ értékkel.

\section{Eredmények ${ }^{9}$}

\subsection{A Mentális Egészség Teszt belső, strukturális validitása}

Először a MET skáláinak belső konzisztenciáját vizsgáltuk meg a két vizsgálat adataira külön-külön és együtt, arra is figyelve, hogy a reliabilitás nem nő-e meg valamelyik tétel elhagyásával (lásd 3. táblázat). A statisztikai elemzéseket - itt és a továbbiakban - a ROPstat (Vargha, 2016), valamint az

\footnotetext{
${ }^{9}$ Mivel az eredmények leírása során részletesen ismertetjük az alkalmazott elemzési eljárásokat, eltekintünk az adatelemzési módszerek külön alfejezetben történő felsorolásától.
} 
Mplus (Muthén \& Muthén, 1998-2011) statisztikai szoftver segítségével végeztük el. A 3. táblázat adatai alapján megállapíthatjuk, hogy a MET minden skálájának belső konzisztenciája minden mintában megfelelő szintú, mivel a Cronbach- $\alpha$ értékek végig 0,70 felettiek, sőt, többségük a 0,80-at is meghaladja (DeVellis, 2016; Nagybányai Nagy, 2006a). A skálák esetleges javítására csak a II. vizsgálat adatai utalnak, amelyben Reziliencia belsó konzisztenciája egy tétel (a 6. számú, „A stresszes eseményeket nehezen viselem.”) elhagyásával észrevehetóen javítható.

3. táblázat. A MET skáláinak belső konzisztenciáját mérő Cronbach- $\alpha$ értékek a két vizsgálatban

\begin{tabular}{|l|c|c|c|}
\hline \multicolumn{1}{|c|}{ Skála } & Tételszám & $\begin{array}{c}\text { I. vizsgálat } \\
(\boldsymbol{n}=\mathbf{1 5 4 0})\end{array}$ & $\begin{array}{c}\text { II. vizsgálat } \\
(\boldsymbol{n}=\mathbf{1 0 8 3})\end{array}$ \\
\hline Jóllét & 3 & 0,845 & 0,899 \\
\hline Savoring & 3 & 0,850 & 0,718 \\
\hline Alkotó-végrehajtó hatékonyság & 5 & 0,847 & 0,768 \\
\hline Önreguláció & 3 & 0,854 & 0,709 \\
\hline Reziliencia & 4 & 0,755 & 0,817 \\
\hline Reziliencia (a 6. tétel elhagyásával) & 3 & 0,743 & 0,861 \\
\hline
\end{tabular}

Ezután a MET skáláinak ötdimenziós modelljét vizsgáltuk meg több lépésben az I. vizsgálat adatain. A skálák interkorrelációit kiszámítva azt láthatjuk, hogy a skálák többsége 0,42-0,62 közötti, mérsékelt, illetve erős kapcsolatban van egymással (lásd 4. táblázat). Ennek alapján a MET olyan modelljét keressük majd, amelyben az öt skálának megfelelő faktorok pozitív korrelációs kapcsolatban vannak egymással. Ez megfelel annak az elméletnek, hogy a mentális egészség különböző komponensei egymással pozitív viszonyban vannak (Ryff \& Marshall, 1999).

Először ötfaktoros feltáró faktorelemzést, röviden EFA-t (Vargha, 2019, 5. fejezet) végeztünk az Mplus szoftverrel annak ellenőrzésére, hogy a MET 18 tétele az általunk feltételezett módon sorolódik-e az öt skálának megfelelő faktorokba. Skáláink erősen nem normális eloszlása (lásd 4. táblázat utolsó két oszlopa) miatt elemzésünkben az MLR robusztus maximum likelihood módszert választottuk (Maydeu-Olivares, 2017), a faktorok korrelációit megengedő Geomin ferde forgatással (Hattori, Zhang, \& Preacher, 2017). Az elemzés eredménye az 5. táblázatban látható ötfaktoros faktorsúlymátrixból olvasható ki. Itt a tételek sorszámai (i1, i2 stb.) a Függelékben látható sorszámoknak felelnek meg, ezt egészíti ki skálájuk kezdőbetúje (i1J, i2Ö stb.). 
4. táblázat. A MET skáláinak interkorrelációi, valamint ferdeségi és csúcsossági együtthatója az I. vizsgálat adatain $(n=1540)$

\begin{tabular}{|l|c|c|c|c|c|c|}
\hline \multicolumn{1}{|c|}{ Skálák } & Savoring & $\begin{array}{c}\text { Alkotó- } \\
\text { végrehajtó } \\
\text { hatékonyság }\end{array}$ & $\begin{array}{c}\text { Ön- } \\
\text { reguláció }\end{array}$ & $\begin{array}{c}\text { Rezilien- } \\
\text { cia }\end{array}$ & Ferdeség & Csúcsosság \\
\hline Jóllét & $0,621^{* * *}$ & $0,630^{* * *}$ & $0,376^{* * *}$ & $0,597^{* * *}$ & $-0,86^{* * *}$ & $0,61^{* * *}$ \\
\hline Savoring & 1 & $0,616^{* * *}$ & $0,214^{* * *}$ & $0,426^{* * *}$ & $-0,80^{* * *}$ & $0,49^{* * *}$ \\
\hline $\begin{array}{l}\text { Alkotó- } \\
\text { végrehajtó } \\
\text { hatékonyság }\end{array}$ & & 1 & $0,257^{* * *}$ & $0,480^{* * *}$ & $-0,80^{* * *}$ & $0,78^{* * *}$ \\
\hline Önreguláció & & & 1 & $0,557^{* * *}$ & $-0,52^{* * *}$ & $-0,44^{* * *}$ \\
\hline Reziliencia & & & & 1 & $-0,28^{* * *}$ & 0,01 \\
\hline
\end{tabular}

Megjegyzés: *** $p<0,001$.

Az 5. táblázat adatai alapján megállapíthatjuk, hogy a Jóllét, a Savoring és az Alkotó-végrehajtó hatékonyság skála minden tétele 1-1 külön faktorra illeszkedik legnagyobb - két kivétellel (i12S: 0,394, i9A: 0,405) mindig 0,50 feletti - súllyal. Ez a rend csak az Önreguláció és a Reziliencia skála esetében bomlik fel annak köszönhetően, hogy a Reziliencia skála i6R tétele 0,485-ös súllyal inkább az Önreguláció skála 3 tételét tartalmazó faktorra illeszkedik elsődlegesen. Megjegyezzük, hogy pont az i6R tétel lógott ki az itemanalízisek során is leginkább a saját skálájából (vö. 3. táblázat). Másik érdekesség: a Reziliencia skála i13R tétele saját skáláján kívül az Önreguláció skála tételeit tartalmazó faktoron is súlyozódik 0,35 feletti, nem elhanyagolható értékú súllyal.

Mindezek alapján a MET-hez olyan korreláló ötfaktoros modellt célszerú választani, amelyből kihagyjuk az i6R tételt, s amelyben lehetővé tesszük, hogy az i13R tétel saját Reziliencia skáláján kívül az Önreguláció skálán is súlyozódjon. Végül az i6R tétel elhagyása után a tételeket mind ahhoz a skálához soroltuk, amelyhez az 5. táblázatban a legnagyobb, de minimálisan 0,35 feletti faktorsúllyal sorolódtak.

Ezt az elemzést több konfirmatív faktoranalízis (CFA; vö. Vargha, 2019, 6. fejezet) segítségével végeztük el, amelyek legfontosabb eredményeit a 6 . táblázatban foglaltuk össze. 
5. táblázat. A MET 18 tételének ötfaktoros feltáró faktorelemzése

MLR módszerrel és Geomin ferde forgatással az I. vizsgálat adatain ( $n=1540)$ : az ötfaktoros faktorsúlymátrix

\begin{tabular}{|c|c|c|c|c|c|}
\hline Tétel & Faktor1 & Faktor2 & Faktor3 & Faktor4 & Faktor5 \\
\hline i1J & 0,656 & 0,072 & $-0,002$ & 0,033 & $-0,008$ \\
\hline i14J & 0,878 & $-0,012$ & 0,015 & 0,005 & 0,028 \\
\hline i18J & 0,773 & 0,006 & $-0,000$ & 0,026 & 0,033 \\
\hline i3S & 0,045 & 0,721 & 0,047 & 0,017 & 0,055 \\
\hline i10S & $-0,017$ & 0,991 & $-0,037$ & $-0,001$ & $-0,042$ \\
\hline i12S & 0,320 & 0,394 & 0,120 & 0,007 & 0,123 \\
\hline i5A & $-0,021$ & 0,007 & 0,770 & 0,010 & 0,069 \\
\hline i7A & $-0,045$ & 0,001 & 0,796 & 0,033 & 0,034 \\
\hline i9A & 0,296 & 0,136 & 0,405 & $-0,016$ & 0,062 \\
\hline i15A & 0,250 & $-0,069$ & 0,633 & 0,023 & $-0,033$ \\
\hline i17A & 0,134 & 0,074 & 0,513 & $-0,040$ & $-0,108$ \\
\hline i2Ö & 0,009 & 0,078 & 0,009 & 0,842 & $-0,015$ \\
\hline i8Ö & 0,080 & 0,024 & 0,012 & 0,784 & $-0,079$ \\
\hline i16Ö & $-0,055$ & $-0,002$ & 0,037 & 0,743 & 0,218 \\
\hline i4R & 0,075 & 0,075 & 0,213 & 0,003 & 0,640 \\
\hline i6R & 0,090 & $-0,059$ & $-0,012$ & 0,486 & 0,253 \\
\hline i11R & 0,183 & 0,057 & 0,048 & $-0,010$ & 0,664 \\
\hline i13R & $-0,024$ & $-0,044$ & $-0,119$ & 0,378 & 0,497 \\
\hline
\end{tabular}

Megjegyzés: A rövidítések feloldása a következő: J = Jóllét, $\mathrm{S}=$ Savoring, A = Alkotóvégrehajtó hatékonyság, Ö = Önreguláció, $\mathrm{R}=$ Reziliencia. A 0,35-nél nagyobb faktorsúlyok celláit szürke háttérrel emeltük ki. Esetükben $p<0,001$.

A 6. táblázat 1. sorában az i6R tétellel csökkentett MET feltáró jellegú, EFA modelljének adekvációs (illeszkedési) mutatói láthatók. RMSEA és SRMR abszolút illeszkedési mutatók, amelyek akkor jeleznek jó illeszkedést, ha értékük 0,06-nál, illetve 0,05-nél kisebb (vö. Vargha, 2019, 122. o.). A modell elfogadható illeszkedésú, ha a két mutató értéke nem haladja meg a 0,08-at, s ez a 6. táblázat minden modellje esetében teljesül. RMSEA esetében az optimális az lenne, ha elméleti értéke nem lenne nagyobb, mint 0,05. Ennek 90\%-os intervallumbecslését tartalmazza a $\mathrm{CI}_{0,90}$ (RMSEA) oszlop. Ez akkor kiváló, ha tartalmazza a 0,05-öt vagy teljes terjedelmében alatta helyezkedik el. Az elméleti 0,05-tól való eltérés tesztjének p-értéke a pClose 
oszlopban található. Ez akkor jó, ha 0,05-nél nagyobb, vagyis ha nem szignifikáns. Az adekvációs mutatók között találunk még két relatív illeszkedési mutatót is, CFI-t és TLI-t (vö. Vargha, 2019, 122. o.). A jó illeszkedést az jelzi, ha CFI értéke eléri a 0,95-öt, TLI-é pedig nem sokkal kisebb, de 0,90-nél feltétlenül nagyobb.

6. táblázat. A MET ötfaktoros modelljére vonatkozó feltáró (EFA) és konfirmatív (CFA) faktorelemzések jóságát méró illeszkedési mutatók

\begin{tabular}{|l|c|c|c|c|c|c|}
\hline Modell (Minta) & RMSEA & CI $_{0,90}(\mathbf{R M S E A})$ & pClose & CFI & TLI & SRMR \\
\hline 1. EFA_I. $(n=1540)$ & 0,059 & $(0,053 ; 0,065)$ & 0,004 & 0,965 & 0,927 & 0,018 \\
\hline 2. CFA_I. $(n=1540)$ & 0,072 & $(0,068 ; 0,076)$ & $<0,001$ & 0,913 & 0,891 & 0,061 \\
\hline 3. CFA+_I. $(n=1540)$ & 0,063 & $(0,059 ; 0,068)$ & $<0,001$ & 0,933 & 0,915 & 0,054 \\
\hline 4. CFA+_II. $(n=1083)$ & 0,051 & $(0,045 ; 0,056)$ & 0,408 & 0,950 & 0,936 & 0,052 \\
\hline 5. CFA+_I.+II. $(n=2623)$ & 0,060 & $(0,057 ; 0,063)$ & $<0,001$ & 0,938 & 0,922 & 0,052 \\
\hline
\end{tabular}

Megjegyzés: Minden elemzés az i6R tétellel csökkentett tesztre vonatkozik. EFA = feltáró faktorelemzés; CFA = megerősítő faktorelemzés. Az I. és a II. a két vizsgálat mintáját jelöli. A CFA utáni + jel azt jelöli, hogy ezekben a modellekben megengedtük, hogy a Savoring skála i3S és i10S tételének reziduálisa korreláljon.

A CFA elemzéseket az i6R tétel elhagyásával redukált 17 tételes teszten kezdtük (2. modell). A modellillesztéshez itt is robusztus módszert választottunk (MLMV), amely korábbi CFA elemzések során jó alternatívája a többdimenziós normalitást megkövetelő hagyományos ML módszernek (vö. Vargha és mtsai, 2019). Ennek outputján az i3S és i10S közti modifikációs index 215 feletti értéke azt jelezte, hogy a modell érdemben javítható lesz, ha megengedjük benne, hogy ennek a két tételnek a reziduálisa (hibatagja) korreláljon egymással. A javulást a 3. modell sorában található kedvezóbb illeszkedési értékek jelzik. Végül a legfontosabb: a II. vizsgálat független mintáján tesztelve a modellt (4. sor), a kapott értékek minden mutató esetében kiváló illeszkedést jeleznek, s ezt erősítik az egyesített I. és II. mintára vonatkozó utolsó sor jó illeszkedést mutató értékei is (5. modell).

Összefoglalva megállapíthatjuk, hogy jó illeszkedési mutatókkal megerósítést nyert a MET 17 tételes tesztjének ötfaktoros modellje az eredeti öt skálával. Mindössze egyetlen tételt (i6R) kellett elhagynunk a 18-ból és egyetlen esetben (i3S és i10S) kellett engedményt tennünk a CFA modelljének azon elvárásából, hogy a tételek reziduálisai korrelálatlanok. A jó illeszkedést úgy sikerült elérni, hogy a végső modellben (lásd pl. 1. ábra) nem engedtünk meg kereszttöltéseket, bár elméleti megfontolások szerint és az EFA elemzések alapján (lásd 5. táblázat) ezt megtehettük volna, ami tovább javította volna a CFA illeszkedési mutatóit. 
A végső modellt és paramétereinek becslését az egyesített I. és II. mintán az 1. ábra mutatja be ${ }^{10}$. Itt a nem standardizált látens faktorok köre mellett azok varianciája $(1,001,0,605,0,937$ stb.), az őket összekötó íveken pedig páronkénti kovarianciáik láthatók. A faktorokból a tételekre mutató nyilak mentén a tételek faktorok szerinti eloállításának együtthatói (faktorsúlyok), a tételek mellett jobbra pedig azok reziduális varianciái $(0,782,0,340$ stb.) láthatók. Minden becsült érték mellett zárójelben a becslés standard hibája került feltüntetésre.

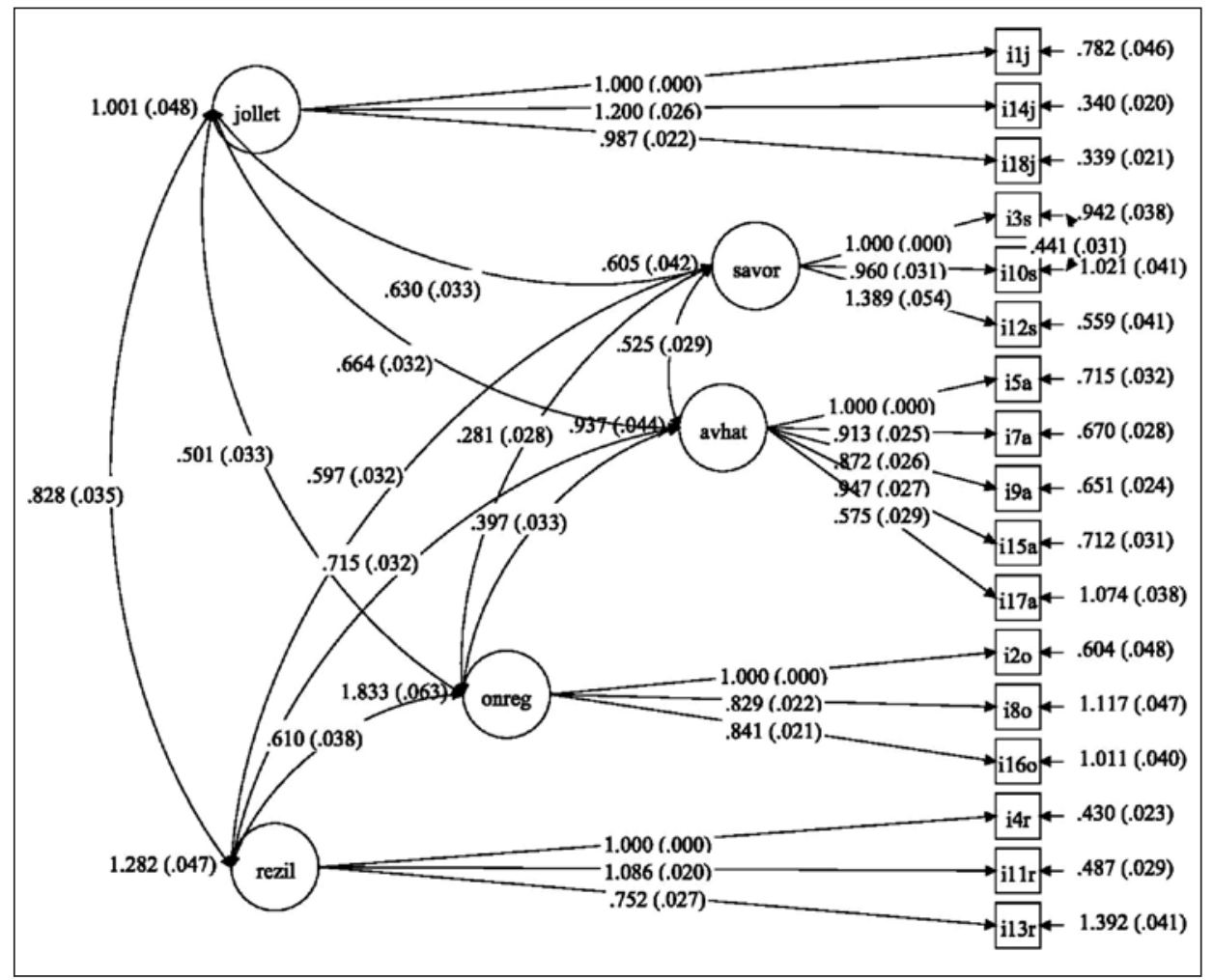

1. ábra. A 17 tételes MET CFA-val feltárt ötdimenziós faktorszerkezete $(n=2623)$

Megjegyzés: A rövidítések feloldása a következő: jollet = Jóllét, savor = Savoring, avhat = Alkotó-végrehajtó hatékonyság, onreg = Önreguláció, rezil = Reziliencia.

10 Az ábrán az Mplus szoftver standardja szerint minden név kisbetús formában és ékezet nélkül látható. 


\subsection{A Mentális Egészség Teszt külső, tartalmi validitása}

A MET tartalmi validitását és az öt skála jellemzőit a két vizsgálat különböző mentális egészséget mérő változóinak segítségével elemeztük. Tekintve, hogy a MET skálái erősen nem normális eloszlásúak (vö. 4. táblázat), az öszszefüggések szorosságának mérésére Spearman-féle $r_{S}$ rangkorrelációt számoltunk, de kiszámítottuk emellett az MV\% megmagyarázott varianciaarányt is, amelyet a Pearson-korreláció négyzeteként kapunk (vö. Vargha, 2019,16 . o.). Ha két kvantitatív változó MV\%-értéke meghaladja az 50-et (vagyis ha $r$ abszolút értéke 0,707-nél nagyobb), akkor elmondhatjuk róluk, hogy tartalmilag lényegében ugyanazt mérik. Ahogy fentebb már említettük $^{11}$, a MET tételei közé is betettük a Rövidített Beck Depresszió Kérdőív 4. tételét, csak nem 4 , hanem 6 válaszlehetőséggel. E két azonos tétel pontértékét korreláltatva $r_{S}=0,65(\mathrm{MV} \%=0,45)$ értékeket kaptunk, amely azt is jelzi, hogy a MET skálák jelentését boncolgatva milyen korrelációs szintet várhatunk el a kritérium validitás teljesüléséhez a parallel tesztek skáláival. A MET skáláinak validálásával kapcsolatban kapott legfontosabb korrelációs eredményeket a 7-11. táblázatban foglaltuk össze. A korrelációk erósségének minősítésével kapcsolatban Cohen (1988, 79-80. o.) konvencióját követtük. Eszerint egy korrelációs kapcsolatot gyengének nevezünk, ha $r$ abszolút értéke nem éri el a 0,1-et (MV\% ugyancsak az 1-et), továbbá rendre közepesnek, nagynak (erősnek), illetve nagyon nagynak (nagyon erősnek), ha $r$ abszolút értéke eléri a 0,3-at (MV\% a 9-et), 0,5-öt (MV\% a 25-öt), illetve a 0,7 -et (MV\% a 49-et).

A 7. táblázat adatai alapján megállapíthatjuk, hogy a 3 tételes Jóllét skála lényegében ugyanazt méri, mint a jóllét hagyományosabb tesztjei, azaz a Globális Jóllét vagy a PERMA Kérdőív összpontszáma. Előbbi teszt esetén nagyon erős az Érzelmi és a Pszichológiai jóllét alskákkal való korreláció, de a leggyengébb korrelációt produkáló Spirituális jóllét alskálával is erős a kapcsolat. A PERMA Kérdőív esetén is a Pozitív érzelmek alskála magyarázza a legtöbb varianciát, s ezzel összhangban nagyon erős az Élettel Való Elégedettség és Diener Virágzás skálájának, valamint a lelki jóllét szubjektív boldogság és szubjektív elégedettség tételének magyarázó ereje is. Mindezek bőven igazolják a Mentális Egészség Teszt Jóllét skálájának kritérium validitását. Jelentéstartalmával összhangban a Jóllét skála erős, 0,6 feletti pozitív kapcsolatban van az Aktuális boldogság kérdőíves tétellel, nagyon erős pozitív kapcsolatban van az élet értelmességét mérő Életcél Kérdőív összpontszámával és nagyon erós negatív kapcsolatban van a depresszióval (Rövidített Beck Depresszió Kérdőív).

11 Lásd a II. vizsgálat változóinak leírását. 
A konvergens validitást jelzik a negatív érzelmi állapotokkal (PERMA Kérdőív Negatív érzelmek alskála, Ideges vagyok és Feszült vagyok kérdőív tétel), valamint a maladaptív sémák jelenlétét mérő skálákkal való közepes vagy olykor erős negatív korrelációk és megmagyarázott variancia arányok. A konvergens validitás (vö. Nagybányai Nagy, 2006b) megerősítéseként értelmezhetjük a flow és a testi jóllét, illetve általános egészségi állapot nem elhanyagolható mértékú szignifikáns magyarázó erejét is.

7. táblázat. A Mentális Egészség Teszt Jóllét skálájával kapcsolatos legfontosabb korrelációs eredmények

\begin{tabular}{|c|c|c|c|c|c|}
\hline \multicolumn{3}{|c|}{ I. vizsgálat } & \multicolumn{3}{|c|}{ II. vizsgálat } \\
\hline $\begin{array}{c}\text { Teszt/ } \\
\text { kérdéstípus }\end{array}$ & Skála/tétel & $\begin{array}{c}\text { Spearman } \\
r_{S}(\mathrm{MV} \%)\end{array}$ & $\begin{array}{c}\text { Teszt/ } \\
\text { kérdéstípus }\end{array}$ & Skála/tétel & $\begin{array}{c}\text { Spearman } \\
r_{S}(\mathrm{MV} \%)\end{array}$ \\
\hline \multirow{5}{*}{$\begin{array}{l}\text { Globális } \\
\text { Jóllét } \\
\text { Kérdőív }\end{array}$} & Összpontszám & $0,699(52,7)$ & \multirow[t]{2}{*}{ Lelki jóllét } & $\begin{array}{l}\text { Szubjektív } \\
\text { boldogság }\end{array}$ & $0,788(66,8)$ \\
\hline & Érzelmi jóllét & $0,786(63,7)$ & & $\begin{array}{l}\text { Szubjektív } \\
\text { elégedettség }\end{array}$ & $0,723(56,5)$ \\
\hline & $\begin{array}{l}\text { Pszichológiai } \\
\text { jóllét }\end{array}$ & $0,687(50,7)$ & \multirow[t]{3}{*}{$\begin{array}{l}\text { Életcél } \\
\text { Kérdőíiv }\end{array}$} & \multirow[t]{3}{*}{ Összpontszám } & \multirow[t]{3}{*}{$0,729(58,8)$} \\
\hline & Szociális jóllét & $0,541(31,8)$ & & & \\
\hline & $\begin{array}{l}\text { Spirituális } \\
\text { jóllét }\end{array}$ & $0,528(30,9)$ & & & \\
\hline \multirow{3}{*}{$\begin{array}{l}\text { PERMA } \\
\text { Kérdőív }\end{array}$} & Összpontszám & $0,754(61,6)$ & \multirow{3}{*}{$\begin{array}{l}\text { Élettel való } \\
\text { Elégedettség } \\
\text { Skála }\end{array}$} & \multirow[t]{3}{*}{ Összpontszám } & \multirow[t]{3}{*}{$0,715(54,0)$} \\
\hline & $\begin{array}{l}\text { Pozitív } \\
\text { érzelmek }\end{array}$ & $0,742(61,1)$ & & & \\
\hline & $\begin{array}{l}\text { Negatív } \\
\text { érzelmek }\end{array}$ & $-0,604(38,7)$ & & & \\
\hline $\begin{array}{l}\text { Diener-féle } \\
\text { Virágzás } \\
\text { skála }\end{array}$ & Összpontszám & $0,701(53,8)$ & \multirow[t]{2}{*}{$\begin{array}{l}\text { WHO Jól-Lét } \\
\text { Kérdőív }\end{array}$} & \multirow[t]{2}{*}{ Összpontszám } & \multirow[t]{2}{*}{$0,652(49,1)$} \\
\hline $\begin{array}{l}\text { Rövidített } \\
\text { PIK }\end{array}$ & Összpontszám & $0,681(49,0)$ & & & \\
\hline \multirow[t]{2}{*}{$\begin{array}{l}\text { Testi és lelki } \\
\text { állapot }\end{array}$} & $\begin{array}{l}\text { Általános } \\
\text { egészség }\end{array}$ & $0,450(21,1)$ & \multirow[t]{2}{*}{ Testi jóllét } & \multirow{2}{*}{$\begin{array}{l}\text { Szubjektív } \\
\text { egészségi } \\
\text { állapot }\end{array}$} & \multirow[t]{2}{*}{$0,432(21,2)$} \\
\hline & Fizikai erő & $0,419(19,4)$ & & & \\
\hline \multirow[t]{2}{*}{ Flow } & Flow1 & $0,454(22,6)$ & \multirow[t]{2}{*}{ Flow } & \multirow[t]{2}{*}{ Flow1 } & \multirow[t]{2}{*}{$0,333(13,8)$} \\
\hline & 3 tétel átlaga & $0,534(30,4)$ & & & \\
\hline
\end{tabular}


7. táblázat folytatása

\begin{tabular}{|c|c|c|c|c|c|}
\hline \multicolumn{3}{|c|}{ I. vizsgálat } & \multicolumn{3}{|c|}{ II. vizsgálat } \\
\hline $\begin{array}{c}\text { Teszt/ } \\
\text { kérdéstípus }\end{array}$ & Skála/tétel & $\begin{array}{l}\text { Spearman } \\
r_{S}(\mathrm{MV} \%)\end{array}$ & $\begin{array}{c}\text { Teszt/ } \\
\text { kérdéstípus }\end{array}$ & Skála/tétel & $\begin{array}{l}\text { Spearman } \\
r_{S}(\mathrm{MV} \%)\end{array}$ \\
\hline \multicolumn{2}{|c|}{ Aktuális boldogság } & $0,638(42,1)$ & \multirow[t]{2}{*}{$\begin{array}{l}\text { Young-féle } \\
\text { Séma Kérdőív }\end{array}$} & Összpontszám & $\begin{array}{r}-0,613 \\
(38,1)\end{array}$ \\
\hline \multirow[t]{2}{*}{$\begin{array}{l}\text { Negatív } \\
\text { élmények }\end{array}$} & Ideges vagyok & $-0,418(16,3)$ & & Negativizmus & $\begin{array}{r}-0,615 \\
(38,7)\end{array}$ \\
\hline & $\begin{array}{l}\text { Feszült } \\
\text { vagyok }\end{array}$ & $-0,431(17,6)$ & \begin{tabular}{|l} 
Rövidített \\
Beck \\
Depresszió \\
Kérdőív
\end{tabular} & Összpontszám & $\begin{array}{r}-0,687 \\
(51,8)\end{array}$ \\
\hline
\end{tabular}

Megjegyzés: $r_{S}=$ Spearman-féle rangkorrelációs együtthatók, MV\% = megmagyarázott varianciaarány. Az 50-nél nagyobb MV\% értékú változókat félkövérrel kiemeltük. A táblázat minden korrelációja és MV\% értéke szignifikáns $(p<0,001)$.

A 8. táblázatban nem okoz meglepetést, hogy a 3 tételes Savoring skála lényegében ugyanazt méri, mint a Rövidített Savoring Hit Kérdőív (kritérium [azon belül pedig konkurens] validitás). Az összpontszám 62,1-es MV\%értéke ebból a szempontból teljesen megnyugtató, mint ahogy az is, hogy az alskálák egyéni magyarázó ereje is rendre $49 \%$ feletti. Közülük is kiemelkedik a Savoring Múlt alskála. A konvergens validitást a mentális egészség más tesztjeinek változóival (Diener-féle Virágzás skála, Életcél Kérdőív, Globális Jóllét Kérdőív, Rövidített PIK, PERMA Kérdőív, Flow) való 0,50feletti rangkorrelációk és $25 \%$-ot meghaladó MV\%-értékek igazolják. A konvergens validitást tovább erősítik a depresszióval (Rövidített Beck Depreszszió Kérdőív), a negatív érzelmi állapotokkal (PERMA Kérdőív Negatív érzelmek alskála), valamint a maladaptív sémák jelenlétét mérő Young-féle Séma Kérdőívvel való közepes vagy erős, negatív irányú korrelációk.

Az Alkotó-végrehajtó hatékonyság skálával kapcsolatos korrelációs eredményeket összefoglaló 9. táblázatban a Rövidített PIK kérdőív Alkotóvégrehajtó viselkedés skálájának kiugró $r_{S}=0,748$ és $M V \%=59,6$ értéke nem meglepetés, hiszen a MET Alkotó-végrehajtó hatékonyság skáláját a Rövidített PIK ezen skálájának 4 tételéből képeztük, kiegészítve őket még egy újabb tétellel. E 4 tétel esetén az eltérés mindössze abból állt, hogy a Rövidített PIK tételei 4-, míg a MET-é 6-pontos Likert-skálák. A konvergens validitás teljesüléseként a Savoring skálához hasonlóan a mentális egészség más tesztjeivel (Diener-féle Virágzás skála, Globális Jóllét Kérdőív, Életcél 
Kérdőív, Rövidített Savoring Hit Kérdőív, PERMA Kérdőív, Rövidített Beck Depresszió Kérdőív) való minimum közepes erősségú kapcsolatokat említhetjük.

8. táblázat. A Mentális Egészség Teszt Savoring skálájával kapcsolatos legfontosabb korrelációs eredmények

\begin{tabular}{|c|c|c|c|c|c|}
\hline \multicolumn{3}{|c|}{ I. vizsgálat } & \multicolumn{3}{|c|}{ II. vizsgálat } \\
\hline $\begin{array}{c}\text { Teszt/ } \\
\text { kérdéstípus }\end{array}$ & Skála/tétel & $\begin{array}{l}\text { Spearman } \\
r_{S}(\mathrm{MV} \%)\end{array}$ & $\begin{array}{c}\text { Teszt/ } \\
\text { kérdéstípus }\end{array}$ & Skála/tétel & $\begin{array}{c}\text { Spearman } r_{S} \\
(\mathrm{MV} \%)\end{array}$ \\
\hline \multirow{4}{*}{$\begin{array}{l}\text { Rövidített } \\
\text { Savoring } \\
\text { Hit } \\
\text { Kérdóív }\end{array}$} & Összpontszám & $0,785(63,3)$ & \multirow{4}{*}{$\begin{array}{l}\text { Életcél } \\
\text { Kérdőív }\end{array}$} & \multirow{4}{*}{$\begin{array}{l}\text { Össz- } \\
\text { pontszám }\end{array}$} & \multirow[t]{4}{*}{$0,541(32,4)$} \\
\hline & $\begin{array}{l}\text { Savoring } \\
\text { Múlt }\end{array}$ & $0,800(65,1)$ & & & \\
\hline & Savoring Jövő & $0,691(51,3)$ & & & \\
\hline & Savoring Jelen & $0,690(49,8)$ & & & \\
\hline \multirow{2}{*}{$\begin{array}{l}\text { Diener-féle } \\
\text { Virágzás } \\
\text { skála }\end{array}$} & \multirow[t]{2}{*}{ Összpontszám } & \multirow[t]{2}{*}{$0,566(35,3)$} & \multirow[t]{2}{*}{ Lelki jóllét } & $\begin{array}{l}\text { Szubjektív } \\
\text { boldogság }\end{array}$ & $0,485(26,4)$ \\
\hline & & & & $\begin{array}{l}\text { Szubjektív } \\
\text { elégedettség }\end{array}$ & $0,438(20,8)$ \\
\hline $\begin{array}{l}\text { Globális } \\
\text { Jóllét } \\
\text { Kérdőíiv }\end{array}$ & Összpontszám & $0,536(32,4)$ & $\begin{array}{l}\text { Élettel való } \\
\text { Elégedettség } \\
\text { Skála }\end{array}$ & $\begin{array}{l}\text { Össz- } \\
\text { pontszám }\end{array}$ & $0,483(25,3)$ \\
\hline $\begin{array}{l}\text { Rövidített } \\
\text { PIK }\end{array}$ & Összpontszám & $0,514(28,3)$ & $\begin{array}{l}\text { WHO Jól- } \\
\text { Lét Kérdőív }\end{array}$ & $\begin{array}{l}\text { Össz- } \\
\text { pontszám }\end{array}$ & $0,466(22,6)$ \\
\hline Flow & 3 tétel átlaga & $0,524(27,7)$ & Flow & Flow1 & $0,350(12,4)$ \\
\hline \multirow[t]{2}{*}{$\begin{array}{l}\text { Testi és } \\
\text { lelki állapot }\end{array}$} & $\begin{array}{l}\text { Általános } \\
\text { egészség }\end{array}$ & $0,279(9,1)$ & \multirow[t]{2}{*}{ Testi jóllét } & \multirow{2}{*}{$\begin{array}{l}\text { Szubjektív } \\
\text { egészségi } \\
\text { állapot }\end{array}$} & \multirow[t]{2}{*}{$0,297(10,1)$} \\
\hline & Fizikai erő & $0,275(9,2)$ & & & \\
\hline \multirow[t]{2}{*}{$\begin{array}{l}\text { PERMA } \\
\text { Kérdőív }\end{array}$} & Összpontszám & $0,492(29,1)$ & $\begin{array}{l}\text { Young-féle } \\
\text { Séma } \\
\text { Kérdóív }\end{array}$ & $\begin{array}{l}\text { Össz- } \\
\text { pontszám }\end{array}$ & $-0,449(20,4)$ \\
\hline & $\begin{array}{l}\text { Negatív } \\
\text { érzelmek }\end{array}$ & $-0,360(15,3)$ & $\begin{array}{l}\text { Rövidített } \\
\text { Beck } \\
\text { Depresszió } \\
\text { Kérdóív }\end{array}$ & $\begin{array}{l}\text { Össz- } \\
\text { pontszám }\end{array}$ & $-0,455(24,5)$ \\
\hline
\end{tabular}

Megjegyzés: $r_{S}=$ Spearman-féle rangkorrelációs együtthatók, MV\% = megmagyarázott varianciaarány. Az 50-nél nagyobb MV\% értékú változókat félkövérrel kiemeltük. A táblázat minden korrelációja és MV\% értéke szignifikáns $(p<0,001)$. 
Az Alkotó-végrehajtó hatékonyság skála speciális kompetencia jelentésével összhangban, a kritérium validitás részeként értelmezhetjük a flow tételek átlagával kapcsolatos erős korrelációt az I. vizsgálatban, illetve a Young-féle Séma Kérdőív Inkompetencia érzés és Teljesítmény kudarc skálájával való, -0,50-et megközelító negatív irányú korrelációt a II. vizsgálatban.

9. táblázat. A Mentális Egészség Teszt Alkotó-végrehajtó hatékonyság skálájával kapcsolatos legfontosabb korrelációs eredmények

\begin{tabular}{|c|c|c|c|c|c|}
\hline \multicolumn{3}{|c|}{ I. vizsgálat } & \multicolumn{3}{|c|}{ II. vizsgálat } \\
\hline $\begin{array}{c}\text { Teszt/ } \\
\text { kérdéstípus }\end{array}$ & Skála/tétel & $\begin{array}{l}\text { Spearman } \\
r_{S}(\mathrm{MV} \%)\end{array}$ & $\begin{array}{l}\text { Teszt/ } \\
\text { kérdéstípus }\end{array}$ & Skála/tétel & $\begin{array}{l}\text { Spearman } \\
r_{S}(\mathrm{MV} \%)\end{array}$ \\
\hline \multirow[t]{2}{*}{$\begin{array}{l}\text { Rövidített } \\
\text { PIK }\end{array}$} & $\begin{array}{l}\text { Alkotó- } \\
\text { végrehajtó } \\
\text { hatékonyság }\end{array}$ & $0,752(59,9)$ & \multirow[t]{2}{*}{ Életcél Kérdőív } & \multirow[t]{2}{*}{$\begin{array}{l}\text { Össz- } \\
\text { pontszám }\end{array}$} & \multirow[t]{2}{*}{$0,591(36,8)$} \\
\hline & $\begin{array}{l}\text { Össz- } \\
\text { pontszám }\end{array}$ & $0,659(45,3)$ & & & \\
\hline Flow & 3 tétel átlaga & $0,639(42,5)$ & Flow & Flow1 & $0,471(21,4)$ \\
\hline $\begin{array}{l}\text { Diener-féle } \\
\text { Virágzás } \\
\text { skála }\end{array}$ & $\begin{array}{l}\text { Össz- } \\
\text { pontszám }\end{array}$ & $0,647(46,2)$ & $\begin{array}{l}\text { Élettel való } \\
\text { Elégedettség } \\
\text { Skála }\end{array}$ & $\begin{array}{l}\text { Össz- } \\
\text { pontszám }\end{array}$ & $0,438(20,2)$ \\
\hline $\begin{array}{l}\text { Globális } \\
\text { Jóllét } \\
\text { Kérdőív }\end{array}$ & $\begin{array}{l}\text { Össz- } \\
\text { pontszám }\end{array}$ & $0,622(42,6)$ & $\begin{array}{l}\text { WHO Jól-Lét } \\
\text { Kérdőív }\end{array}$ & $\begin{array}{l}\text { Össz- } \\
\text { pontszám }\end{array}$ & $0,438(19,2)$ \\
\hline $\begin{array}{l}\text { Rövidített } \\
\text { Savoring Hit } \\
\text { Kérdőív }\end{array}$ & $\begin{array}{l}\text { Össz- } \\
\text { pontszám }\end{array}$ & $0,584(37,7)$ & $\begin{array}{l}\text { Rövidített Beck } \\
\text { Depresszió } \\
\text { Kérdőív }\end{array}$ & $\begin{array}{l}\text { Össz- } \\
\text { pontszám }\end{array}$ & $-0,445(23,2)$ \\
\hline \multirow[t]{2}{*}{$\begin{array}{l}\text { PERMA } \\
\text { Kérdőív }\end{array}$} & $\begin{array}{l}\text { Össz- } \\
\text { pontszám }\end{array}$ & $0,520(33,4)$ & \multirow[t]{2}{*}{$\begin{array}{l}\text { Young-féle } \\
\text { Séma Kérdőív }\end{array}$} & $\begin{array}{l}\text { Inkompe- } \\
\text { tencia érzés }\end{array}$ & $-0,471(24,3)$ \\
\hline & $\begin{array}{l}\text { Negatív } \\
\text { érzelmek }\end{array}$ & $-0,374(16,5)$ & & $\begin{array}{l}\text { Teljesítmény } \\
\text { kudarc }\end{array}$ & $-0,494(29,4)$ \\
\hline
\end{tabular}

Megjegyzés: $r_{S}=$ Spearman-féle rangkorrelációs együtthatók, $\mathrm{MV} \%$ = megmagyarázott varianciaarány. Az 50-nél nagyobb MV\% értékú változókat félkövérrel kiemeltük. A táblázat minden korrelációja és MV\% értéke szignifikáns $(p<0,001)$.

Az Önreguláció skálával kapcsolatos korrelációs eredményeket összefoglaló 10. táblázatban a Rövidített PIK Önreguláció skálájának kiugró $r_{S}=0,811$ és MV\% = 67,1 értéke ugyancsak várható volt, hiszen a MET ezen skáláját a Rövidített PIK azonos nevú skálájának 3 tételéből képeztük. A konvergens 
validitás teljesüléseként itt is megemlíthetjük a mentális egészség más tesztjeivel (pl. Globális Jóllét Kérdőív, Életcél Kérdőív, PERMA Kérdőív, Rövidített Beck Depresszió Kérdőív) való többnyire közepes szintú szignifikáns korrelációkat.

Az Önreguláció skála emocionalitás és indulatszabályozás jelentésével összhangban a kritérium validitás részeként értelmezhetjük a PERMA Kérdőív Negatív érzelmek, illetve a Young-féle Séma Kérdőív Elégtelen önkontroll, Negativizmus és Elhagyatottság skálájával való minimum közepes szintú szignifikáns korrelációkat.

10. táblázat. A Mentális Egészség Teszt Önreguláció skálájával kapcsolatos legfontosabb korrelációs eredmények

\begin{tabular}{|c|c|c|c|c|c|}
\hline \multicolumn{3}{|c|}{ I. vizsgálat } & \multicolumn{3}{|c|}{ II. vizsgálat } \\
\hline $\begin{array}{c}\text { Teszt/ } \\
\text { kérdéstípus }\end{array}$ & Skála/tétel & $\begin{array}{l}\text { Spearman } \\
r_{S}(\mathrm{MV} \%)\end{array}$ & $\begin{array}{c}\text { Teszt/ } \\
\text { kérdéstípus }\end{array}$ & Skála/tétel & $\begin{array}{l}\text { Spearman } \\
r_{S}(\mathrm{MV} \%)\end{array}$ \\
\hline \multirow{3}{*}{$\begin{array}{l}\text { Rövidített } \\
\text { PIK }\end{array}$} & Önreguláció & $0,813(67,8)$ & \multirow{3}{*}{$\begin{array}{l}\text { Életcél } \\
\text { Kérdőíiv }\end{array}$} & \multirow{3}{*}{$\begin{array}{l}\text { Össz- } \\
\text { pontszám }\end{array}$} & \multirow[t]{3}{*}{$0,294(8,7)$} \\
\hline & Összpontszám & $0,679(48,4)$ & & & \\
\hline & Reziliencia & $0,531(28,6)$ & & & \\
\hline \multirow[t]{2}{*}{$\begin{array}{l}\text { PERMA } \\
\text { Kérdoóív }\end{array}$} & Összpontszám & $0,474(20,8)$ & \multirow{5}{*}{$\begin{array}{l}\text { Young-féle } \\
\text { Séma } \\
\text { Kérdőív }\end{array}$} & $\begin{array}{l}\text { Össz- } \\
\text { pontszám }\end{array}$ & $-0,342(11,9)$ \\
\hline & $\begin{array}{l}\text { Negatív } \\
\text { érzelmek }\end{array}$ & $-0,545(30,8)$ & & $\begin{array}{l}\text { Negativiz- } \\
\text { mus }\end{array}$ & $-0,324(11,4)$ \\
\hline \multirow{3}{*}{$\begin{array}{l}\text { Globális } \\
\text { Jóllét } \\
\text { Kérdőív }\end{array}$} & Összpontszám & $0,398(15,4)$ & & $\begin{array}{l}\text { Elhagya- } \\
\text { tottság }\end{array}$ & $-0,320(10,6)$ \\
\hline & Érzelmi jóllét & $0,438(18,8)$ & & \multirow{2}{*}{$\begin{array}{l}\text { Elégtelen } \\
\text { önkontroll }\end{array}$} & \multirow[t]{2}{*}{$-0,374(15,1)$} \\
\hline & $\begin{array}{l}\text { Pszichológiai } \\
\text { jóllét }\end{array}$ & $0,413(16,9)$ & & & \\
\hline \multirow{2}{*}{$\begin{array}{l}\text { Negatív } \\
\text { élmények }\end{array}$} & Ideges vagyok & $-0,415(16,0)$ & \multirow{2}{*}{$\begin{array}{l}\text { Rövidített } \\
\text { Beck } \\
\text { Depresszió } \\
\text { Kérdóív }\end{array}$} & \multirow{2}{*}{$\begin{array}{l}\text { Össz- } \\
\text { pontszám }\end{array}$} & \multirow[t]{2}{*}{$-0,244(5,7)$} \\
\hline & $\begin{array}{l}\text { Feszült } \\
\text { vagyok }\end{array}$ & $-0,406(15,8)$ & & & \\
\hline
\end{tabular}

Megjegyzés: $r_{S}=$ Spearman-féle rangkorrelációs együtthatók, MV\% = megmagyarázott varianciaarány. Az 50-nél nagyobb MV\% értékú változókat félkövérrel kiemeltük. A táblázat minden korrelációja és MV\% értéke szignifikáns $(p<0,001)$.

A Reziliencia skálával kapcsolatos korrelációs eredmények a 11. táblázatban láthatók. A kritérium validitás részeként értelmezhetjük az általános pszichológiai immunkompetenciát mérő Rövidített PIK összpontszámmal 
tapasztalt erős pozitív kapcsolatot. A Rövidített PIK Reziliencia alskálával mért korreláció ennél némileg gyengébb, ami azt jelzi, hogy a Rövidített PIK ennek a konstruktumnak egy másik vetületét méri.

A konvergens validitás teljesüléseként itt is megemlíthetjük a mentális egészség különböző tesztjeivel (Életcél Kérdőív, Globális Jóllét Kérdőív, PERMA Kérdőív, WHO Jól-Lét Kérdőív stb.) való szoros kapcsolatot. A konvergens validitást jelzik a depresszióval (Rövidített Beck Depresszió Kérdőív), a negatív érzelmi állapotokkal (PERMA Kérdőív Negatív érzelmek alskála, Ideges vagyok és Feszült vagyok kérdő́iv tétel), valamint a maladaptív sémák jelenlétét mérő skálákkal való minimum közepes szintú negatív korrelációk és MV\% értékek, amelyek azt jelzik, hogy a reziliencia magas szintje egyfajta védelmet jelent a depresszióval, valamint a negatív érzelmekkel és attitúdökkel szemben. Ezt erősíti a flow-val való közepes szorosságú kapcsolat is. A flow-hoz ugyanis elengedhetetlen bizonyos viselkedési kompetencia, amely befektetésnek is tekinthetó az egyén megküzdő rendszerében.

Végül a diszkriminációs validitás (Nagybányai Nagy, 2006b) teljesüléséhez megvizsgáltuk, hogy az öt skála mennyire függ egymástól, vagyis hogy varianciájukban rendre mekkora az a rész, amit a többi négy skála nem magyaráz meg. Ezt többszörös lineáris regresszió (TLR) elemzésekkel számítottuk ki a két vizsgálat együttes mintáján $(n=2623)$. A függó változó rendre az öt skála (Jóllét, Savoring, Alkotó-végrehajtó hatékonyság, Önreguláció, Reziliencia), a független változókat pedig minden esetben a maradék négy skála képezte. A megmagyarázott variancia (MV\%) értékét a TLR $\mathrm{R}^{2}$-értékével mértük. A kapott értékek rendre a következők lettek: 0,557, 0,435, 0,415, 0,174, 0,444, amelynek alapján skálánként az egyedi, a többi négy skála által meg nem magyarázott varianciaarány: 44,3\%, 56,5\%, 58,5\%, $82,6 \%$ és 55,6. A legkisebb, 44,3\%-os egyediségú skála a Jóllét, a legmagasabb, 82,6\%-os egyediségú skála pedig az Önreguláció. Ezt a diszkriminációs validitást megerősítő eredményt úgy értelmezhetjük, hogy minden skálának van egy tekintélyes, minimum $44 \%$-os olyan egyedi része, amelyet a többi négy skála nem fed le. A legmagasabb, 82,6\%-os egyediségú skála az Önreguláció, de ez az arány a Savoring, Alkotó-végrehajtó hatékonyság és Reziliencia skála esetén is meghaladja az 55\%-ot, vagyis ezeknél a skáláknál az egyedi rész minimum 10 százalékponttal nagyobb, mint a többi által megmagyarázott arány (MV\%). A Jóllét az egyetlen, amelyet több mint $50 \%$-ban megmagyaráz a többi skála. Ez arra utal, hogy a mentális egészség összetevői között a jóllét centrális helyet foglal el. 
11. táblázat. A Mentális Egészség Teszt rövidített (3 tételes) Reziliencia skálájával kapcsolatos legfontosabb korrelációs eredmények

\begin{tabular}{|c|c|c|c|c|c|}
\hline \multicolumn{3}{|c|}{ I. vizsgálat } & \multicolumn{3}{|c|}{ II. vizsgálat } \\
\hline $\begin{array}{c}\text { Teszt/ } \\
\text { kérdéstípus }\end{array}$ & Skála/tétel & $\begin{array}{c}\text { Spearman } \\
r_{S}(\mathrm{MV} \%)\end{array}$ & $\begin{array}{c}\text { Teszt/ } \\
\text { kérdéstípus }\end{array}$ & Skála/tétel & $\begin{array}{c}\text { Spearman } \\
r_{S}(\mathrm{MV} \%)\end{array}$ \\
\hline \multirow[t]{2}{*}{$\begin{array}{l}\text { Rövidített } \\
\text { PIK }\end{array}$} & $\begin{array}{l}\text { Össz- } \\
\text { pontszám }\end{array}$ & $0,622(40,6)$ & \multirow[t]{2}{*}{$\begin{array}{l}\text { Életcél } \\
\text { Kérdőíiv }\end{array}$} & \multirow[t]{2}{*}{$\begin{array}{l}\text { Össz- } \\
\text { pontszám }\end{array}$} & \multirow[t]{2}{*}{$0,578(35,1)$} \\
\hline & Reziliencia & $0,486(24,7)$ & & & \\
\hline \multirow[t]{2}{*}{$\begin{array}{l}\text { PERMA } \\
\text { Kérdöív }\end{array}$} & \multirow{2}{*}{$\begin{array}{l}\text { Össz- } \\
\text { pontszám } \\
\text { Negatív } \\
\text { érzelmek }\end{array}$} & \multirow[t]{2}{*}{$\begin{array}{c}0,580(34,9) \\
-0,532(30,2)\end{array}$} & \multirow[t]{2}{*}{ Lelki jóllét } & $\begin{array}{l}\text { Szubjektív } \\
\text { boldogság }\end{array}$ & $0,490(25,6)$ \\
\hline & & & & $\begin{array}{l}\text { Szubjektív } \\
\text { elégedettség }\end{array}$ & $0,442(21,0)$ \\
\hline \multirow{3}{*}{$\begin{array}{l}\text { Globális } \\
\text { Jóllét } \\
\text { Kérdőív }\end{array}$} & $\begin{array}{l}\text { Össz- } \\
\text { pontszám }\end{array}$ & $0,498(27,3)$ & \multirow[t]{3}{*}{$\begin{array}{l}\text { WHO Jól- } \\
\text { Lét Kérdőív }\end{array}$} & \multirow[t]{3}{*}{$\begin{array}{l}\text { Össz- } \\
\text { pontszám }\end{array}$} & \multirow[t]{3}{*}{$0,454(21,8)$} \\
\hline & $\begin{array}{l}\text { Érzelmi } \\
\text { jóllét }\end{array}$ & $0,556(33,1)$ & & & \\
\hline & $\begin{array}{l}\text { Pszichológiai } \\
\text { jóllét }\end{array}$ & $0,524(29,5)$ & & & \\
\hline $\begin{array}{l}\text { Rövidített } \\
\text { Savoring } \\
\text { Hit Kérdőív }\end{array}$ & $\begin{array}{l}\text { Össz- } \\
\text { pontszám }\end{array}$ & $0,455(20,6)$ & $\begin{array}{l}\text { Élettel való } \\
\text { Elégedettség } \\
\text { Skála }\end{array}$ & $\begin{array}{l}\text { Össz- } \\
\text { pontszám }\end{array}$ & $0,422(19,1)$ \\
\hline Flow & 3 tétel átlaga & $0,435(18,9)$ & Flow & Flow1 & $0,334(12,9)$ \\
\hline \multirow[t]{3}{*}{$\begin{array}{l}\text { Negatív } \\
\text { élmények }\end{array}$} & $\begin{array}{l}\text { Ideges } \\
\text { vagyok }\end{array}$ & $-0,382(14,2)$ & \multirow{2}{*}{$\begin{array}{l}\text { Young-féle } \\
\text { Séma } \\
\text { Kérdóíiv }\end{array}$} & $\begin{array}{l}\text { Össz- } \\
\text { pontszám }\end{array}$ & $-0,546(31,8)$ \\
\hline & \multirow[t]{2}{*}{$\begin{array}{l}\text { Feszült } \\
\text { vagyok }\end{array}$} & \multirow[t]{2}{*}{$-0,388(15,1)$} & & $\begin{array}{l}\text { Negativiz- } \\
\text { mus }\end{array}$ & $-0,580(35,5)$ \\
\hline & & & $\begin{array}{l}\text { Rövidített } \\
\text { Beck } \\
\text { Depresszió } \\
\text { Kérdőív }\end{array}$ & $\begin{array}{l}\text { Össz- } \\
\text { pontszám }\end{array}$ & $-0,543(30,9)$ \\
\hline
\end{tabular}

Megjegyzés: $r_{S}=$ Spearman-féle rangkorrelációs együtthatók, MV\% = megmagyarázott varianciaarány. A táblázat minden korrelációja és MV\% értéke szignifikáns 0-tól $(p<0,001)$. 


\subsection{A szociodemográfiai mutatókkal kapott összefüggések}

A tanulmányunkban taglalt revideált MET öt skálája és a szociodemográfiai mutatók közti kapcsolatot vizsgálva igen sok a szignifikáns eredmény, de ezek a kapcsolatok jellemzően gyengék. Például a vizsgált korrelációs öszszefüggések $91 \%$-a esetében $r_{S}<|0,20|$. Ezek részletes ismertetése meghaladja cikkünk kereteit, ezért velük kapcsolatban most csak a legmarkánsabb eredmények bemutatására szorítkozunk. Megjegyezzük, hogy az öt skálát tételeik átlagaként definiáltuk, hogy értékük szintén az 1-6 tartományban mozogjon.

A nem és az életkor hatását a két vizsgálat egyesített mintájában az érvényes nemi értékkel rendelkező személyekkel elemeztük $(n=2620)$. Az öt skála közül Savoring esetében különbözött értelmezhető mértékben a két nem átlaga (férfiak: 4,34; nők: 4,66), 1 körüli szórások mellett. A különbség mind a kétmintás $t$-próba $(t(2618)=-6,500 ; p<0,001)$, mind a MannWhitney-féle $U$-próba $(Z=-6,208 ; p<0,001)$ és a szóráshomogenitás sérülésére robusztus rangsorolásos Brunner-Munzel-próba $(\mathrm{BM}(1016)=-6,257$; $p<0,001)$ esetén szignifikáns volt, de ennél is fontosabb, hogy a Cohen-féle hatásmérték $(d=0,30)$ bár gyenge, de szakmailag már értelmezhető szintú. Ugyanitt az MV\% mértékeként használható eta-négyzet értéke 0,016, vagyis 1,6\%. A nők fölénye minden életkori kategóriában megnyilvánult (lásd 2. ábra).

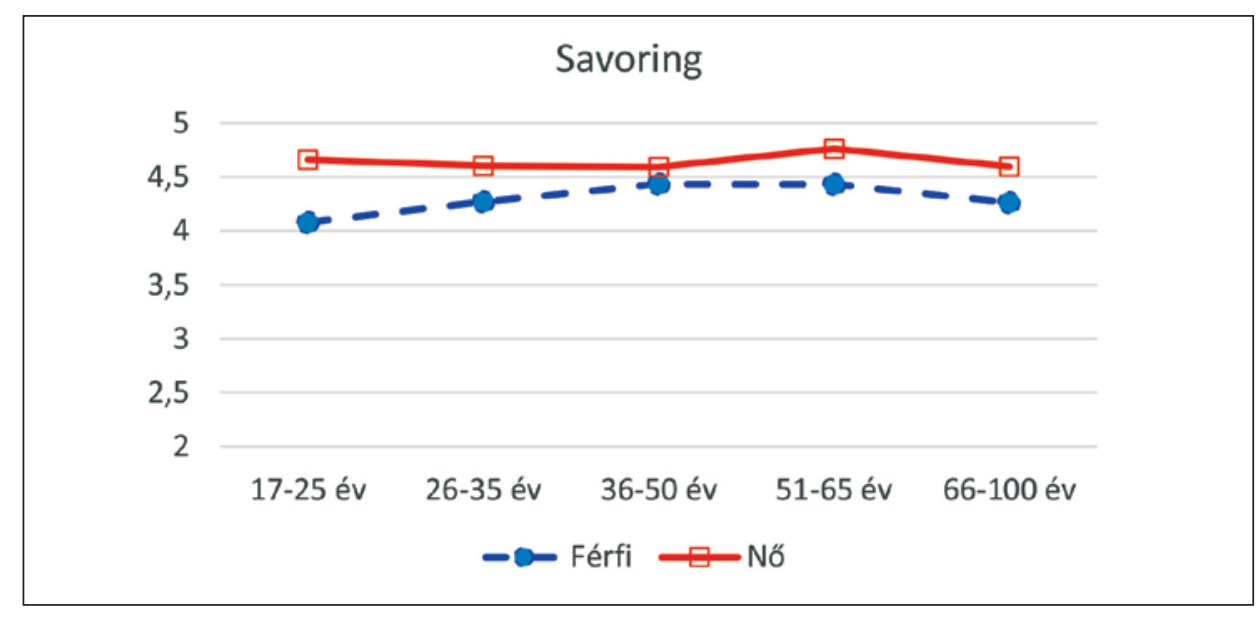

2. ábra. A Savoring skála átlaga nem és életkori övezet szerinti bontásban $(n=2620)$ 
Ugyanezen a mintán az életkor jelentősebb hatását az Önreguláció és a Reziliencia skála esetében figyelhettük meg. Kétszempontos varianciaanalízist alkalmazva az életkor főhatása mindkét skálára szignifikáns volt (Önreguláció: $F(4 ; 2610)=49,960 ; p<0,001$; Reziliencia: $F(4 ; 2610)=22,990$; $p<0,001)$, elóbbi esetén $0,071(=7,1 \%)$, utóbbi esetén $0,034(=3,4 \%)$ etanégyzet hatásértékkel, amelyek a fenti nemi hatásnál láthatóan erősebbek. Az Önreguláció esetében a Nem $\times$ Kor interakciós hatás is szignifikáns volt $(F(4 ; 2612)=3,589 ; p=0,006)$, amely abból fakadt, hogy nőknél az Önreguláció szintje az életkor növekedésével végig lineárisan nő, míg férfiaknál ez csak a 26-50 életkori tartományban figyelhetó meg (lásd 3. ábra).

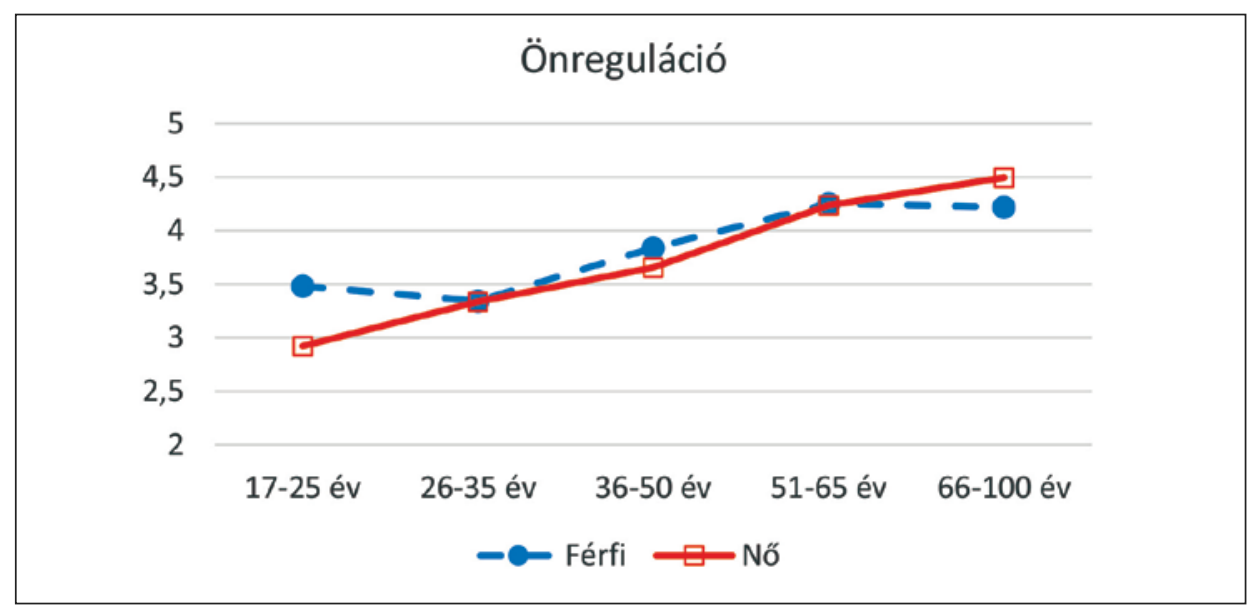

3. ábra. Az Önreguláció skála átlaga nem és életkori övezet szerinti bontásban $(n=2620)$

Megjegyezzük, hogy a MET skáláinak erősen nem normális eloszlású volta (lásd 4. táblázat) miatt a nagyságszintek összehasonlítására elvégeztük a kétszempontos sztochasztikus összehasonlítás elemzését is (vö. Vargha, 2004; 2016), s ugyanolyan szinten szignifikáns eredményeket kaptunk. Az Önreguláció nőknél markánsabb növekvő trendjét az életkor szerint az is megerősíti, hogy az Önreguláció és az életkor közötti Spearman-féle rangkorrelációs együttható értéke nőknél 0,385 ( $p<0,001)$, férfiaknál pedig csak $0,272(p<0,001)$ volt, amely az elóbbi értéknél a Fisher-féle Z-transzformáció eredménye szerint szignifikánsan kisebb $(z=2,750 ; p=0,006)$. Az életkorral való korreláció a Reziliencia esetében is mindkét nemnél $p<0,001$ szinten szignifikáns volt, de értékeik (férfiaknál $r_{S}=0,162$, nőknél $r_{S}=0,200$ ) nem tértek el egymástól szignifikánsan $(z=0,851 ; p=0,395)$. 
A többi szociodemográfiai változó hatását a két vizsgálati csoportban külön-külön végeztük. Az iskolázottsági szinttel kapcsolatban a legerősebb pozitív összefüggést az Alkotó-végrehajtó hatékonysággal (az I. mintában $r_{S}=0,180$, a II. mintában $r_{S}=0,126$, mindkettő $p<0,001$ szinten szignifikáns). Ennél erősebb hatása volt az anyagi helyzetnek mindkét mintában. Az I. mintában az anyagi helyzet a Jólléttel $r S=0,222$, az Alkotó-végrehajtó hatékonysággal pedig $r_{S}=0,129$ szorosságú (mindkettő $p<0,001$ szinten szignifikáns) pozitív kapcsolatban volt. Ugyanakkor a II. mintában a szubjektív anyagi helyzet a Jólléttel $r_{S}=0,232$, Rezilienciával $r_{S}=0,199$, Alkotóvégrehajtó hatékonysággal pedig $r_{S}=0,172$ szorosságú, $p<0,001$ szinten szignifikáns pozitív kapcsolatban volt. Kissé erősebb, de hasonló mintázatot kaptunk itt a havi jövedelemmel való korrelációk esetén is (Jóllét: $r_{S}=0,168$, Reziliencia: $r_{S}=0,267$, Alkotó-végrehajtó hatékonyság: $\left.r_{S}=0,249\right)$. Az anyagi helyzet tehát pozitív hatással van a jóllétre, a lelki ellenálló képességre és a nehéz helyzetekkel való megküzdésre. A többi összefüggés közül talán a vallás fontossága változót említhetjük, amely a II. mintában a Jóllét $\left(r_{S}=\right.$ $0,139)$ és a Savoring $\left(r_{S}=0,129\right)$ skálával igen gyenge, de szignifikáns $(p<$ $0,001)$ pozitív kapcsolatban volt.

\section{Gyakorlati instrukciók a Mentális Egészség Teszt használatához}

A tanulmányban ismertetett Mentális Egészség Teszt (MET) felnóttek számára megszerkesztett 18 tételes kérdőíve a Függelékben látható. Ebból egy tétel (6. A stresszes eseményeket nehezen viselem) a pszichometriai elemzések eredménye alapján elhagyható, vagyis a MET javított verziója 17 tételes, skálánként (Jóllét, Savoring, Alkotó-végrehajtó hatékonyság, Önreguláció, Reziliencia) rendre 3, 3, 5, 3, 3 tétellel. A kérdőívet esetenként (ahogy vizsgálatainkban is történt) ki lehet egészíteni néhány más jellegú (pl. flow) tétellel. A javasolt bevezető instrukció a Függelékben olvasható.

A skálák pontértékét a skálába tartozó és 6-pontos Likert-skálát követő tételek átlagaként definiáljuk (vö. Függelék). A mentális egészség szintjének egészleges megítéléséhez olykor érdemes lehet az öt skála pontértékének átlagát (MET átlag) is meghatározni. E skálák értékkészlete minden esetben 1 és 6 közötti, értelmezésükhöz fontos lehet átlaguk és szórásuk ismerete (lásd 12. táblázat utolsó oszlopa). Mivel a skálák erősen nem normális eloszlásúak, ami abból is látható, hogy átlaguk minden esetben az 1-6 értéktartomány felső széle felé tolódik el, egy-egy skálaérték nagyságának megítéléséhez fontos tudni, hogy az érték milyen övezetbe esik. Ehhez segítségképpen skálánként elkészítettük a teljes értéktartomány 5\%-15\%-60\%-15\%-5\% 
megoszlását legjobban megközelítő övezeteket a két vizsgálat 2623 fős egyesített mintája alapján (lásd 12. táblázat). Mivel az előző alpont elemzései alapján a Savoring skála nagyságszintje érdemben különbözött a két nemnél, a két nemre külön standardot is megadtunk. Ugyanennél a skálánál „nagyon magas” övezetet nem lehetett definiálni, mert a minta 11,6\%-a (férfiak: 9,1\%, nők: 12,4\%), vagyis 5\%-nál jóval nagyobb része ért el maximális, 6 pontos skálaértéket.

12. táblázat. A Mentális Egészség Teszt skáláinak értelmezését elősegítő övezetek skálánként (utánuk zárójelben az övezet előfordulási aránya*) a két vizsgálat 2623 fős egyesített mintája alapján

\begin{tabular}{|c|c|c|c|c|c|c|}
\hline Skála & $\begin{array}{l}\text { Nagyon } \\
\text { alacsony }\end{array}$ & Alacsony & Átlagos & Magas & $\begin{array}{c}\text { Nagyon } \\
\text { magas }\end{array}$ & $\begin{array}{c}\text { Skálaátlag } \\
\text { (szórás) }\end{array}$ \\
\hline Jóllét & $\begin{array}{l}1-2,1 \\
(5,6 \%)\end{array}$ & $\begin{array}{l}2,2-3,5 \\
(13,6 \%)\end{array}$ & $\begin{array}{l}3,6-5,2 \\
(54,8 \%)\end{array}$ & $\begin{array}{l}5,3-5,8 \\
(18,3 \%)\end{array}$ & $\begin{array}{l}5,9-6 \\
(7,7 \%)\end{array}$ & $\begin{array}{c}4,40 \\
(1,14)\end{array}$ \\
\hline Savoring & $\begin{array}{l}1-2,5 \\
(4,5 \%)\end{array}$ & $\begin{array}{l}2,6-3,7 \\
(17,6 \%)\end{array}$ & $\begin{array}{l}3,8-5,5 \\
(56,3 \%)\end{array}$ & $\begin{array}{c}5,6-6 \\
(21,5 \%)\end{array}$ & - & $\begin{array}{c}4,58 \\
(1,07)\end{array}$ \\
\hline Savoring (férfiak) & $\begin{array}{c}1-2,2 \\
(4,8 \%)\end{array}$ & $\begin{array}{l}2,3-3,4 \\
(18,2 \%)\end{array}$ & $\begin{array}{l}3,5-5,2 \\
(51,8 \%)\end{array}$ & $\begin{array}{c}5,3-6 \\
(25,2 \%)\end{array}$ & - & $\begin{array}{c}4,34 \\
(1,13)\end{array}$ \\
\hline Savoring (nők) & $\begin{array}{c}1-2,7 \\
(5,9 \%)\end{array}$ & $\begin{array}{l}2,8-3,7 \\
(14,3 \%)\end{array}$ & $\begin{array}{l}3,8-5,5 \\
(56,0 \%)\end{array}$ & $\begin{array}{c}5,6-6 \\
(23,8 \%)\end{array}$ & - & $\begin{array}{c}4,66 \\
(1,03)\end{array}$ \\
\hline $\begin{array}{l}\text { Alkotó-végrehajtó } \\
\text { hatékonyság }\end{array}$ & $\begin{array}{l}1-2,8 \\
(5,5 \%)\end{array}$ & $\begin{array}{l}2,9-3,9 \\
(15,9 \%)\end{array}$ & $\begin{array}{c}4-5,3 \\
(57,4 \%)\end{array}$ & $\begin{array}{l}5,4-5,8 \\
(17,0 \%)\end{array}$ & $\begin{array}{l}5,9-6 \\
(4,2 \%)\end{array}$ & $\begin{array}{c}4,55 \\
(0,92)\end{array}$ \\
\hline Önreguláció & $\begin{array}{l}1-1,4 \\
(5,6 \%)\end{array}$ & $\begin{array}{l}1,5-2,5 \\
(13,3 \%)\end{array}$ & $\begin{array}{l}2,6-4,9 \\
(56,8 \%)\end{array}$ & $\begin{array}{c}5-5,8 \\
(18,7 \%)\end{array}$ & $\begin{array}{l}5,9-6 \\
(5,7 \%)\end{array}$ & $\begin{array}{c}3,76 \\
(1,32)\end{array}$ \\
\hline Reziliencia & $\begin{array}{c}1-1,5 \\
(4,7 \%)\end{array}$ & $\begin{array}{l}1,6-2,7 \\
(15,4 \%)\end{array}$ & $\begin{array}{l}2,8-4,9 \\
(59,7 \%)\end{array}$ & $\begin{array}{c}5-5,5 \\
(13,8 \%)\end{array}$ & $\begin{array}{l}5,6-6 \\
(6,4 \%)\end{array}$ & $\begin{array}{c}3,78 \\
(1,19)\end{array}$ \\
\hline MET átlag & $\begin{array}{l}1-2,68 \\
(5,0 \%)\end{array}$ & $\begin{array}{c}2,69-3,55 \\
(15,1 \%)\end{array}$ & $\begin{array}{c}3,56-4,91 \\
(59,7 \%)\end{array}$ & $\begin{array}{c}4,92-5,46 \\
(15,3 \%)\end{array}$ & $\begin{array}{c}5,461-6 \\
(4,9 \%)\end{array}$ & $\begin{array}{c}4,21 \\
(0,83)\end{array}$ \\
\hline
\end{tabular}

Megjegyzés: * soronként az arányok összege a kerekítés miatt nem ad ki minden esetben $100 \%$-ot.

Két ábrával szemléltetjük, hogy milyen fontos annak ismerete, hogy a vizsgált személy egy-egy skálán melyik övezetbe eső értéket ér el. A 4. ábra a Jóllét skála övezeteinek hatását mutatja a Rövidített Beck Depresszió Kérdőív és a WHO Jól-Lét Kérdőív szintjére a II. vizsgálat adatain $(n=1083)$. Jól látható itt, hogy az 1-4 skálán a legalacsonyabb Jóllét övezetbe eső személyek depresszió átlaga 2,5 fölé emelkedik, míg a „magas” és a „nagyon 
magas" övezetbe esők depresszió átlaga alig megy 1 fölé. Hasonló mértékú különbséget láthatunk a WHO Jól-Lét Kérdőív esetén is, csak fordított irányban. Itt a legalacsonyabb Jóllét övezetbe eső személyek WHO Jól-Lét Kérdőív átlaga 2 alatt van, míg a legfelső két övezetbe esőké 3,5 körüli. ${ }^{12}$

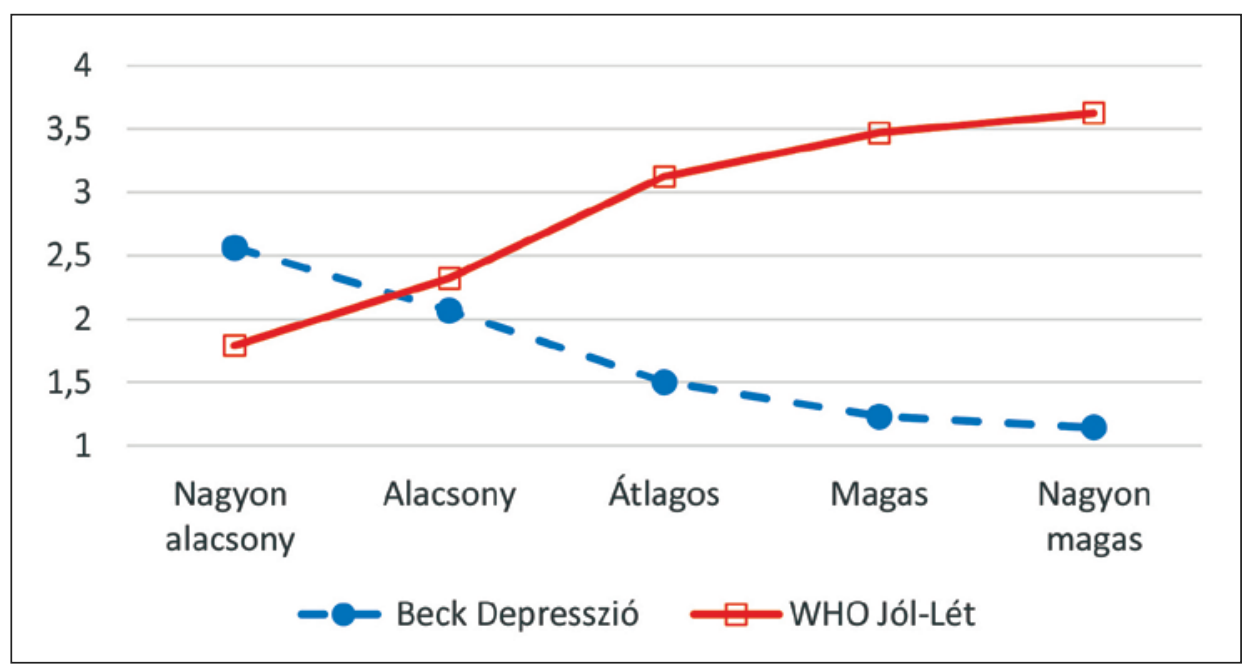

4. ábra. A Jóllét skála övezeteinek hatása a Beck-féle Depresszió skála és a WHO Jól-Lét Kérdóív szintjére (II. vizsgálat, $n=1083$ )

Az 5. ábra az Alkotó-végrehajtó hatékonyság skála övezeteinek hatását mutatja az I. vizsgálat három flow tételének átlagos szintjére $(n=1540)$. Jól látható itt, hogy az 1-6 értékskálán ${ }^{13}$ a legalacsonyabb Alkotó-végrehajtó hatékonyság övezetbe eső személyek Flow-átlaga mindössze 3,5 körüli, míg a „nagyon magas” övezetbe esők Flow-átlaga az 5,5-öt is meghaladja.

12 Az eredeti kérdőívek skáláit nem a tételek átlagaként, hanem összegeként definiálják. Ez a technikai jellegú különbség sem a korrelációkra sem az átlagok szerinti összehasonlításokra nincs hatással. Mi azért választottuk az átlagolást, hogy a 4. ábrán érthetóbbek legyenek az illusztrált eredmények.

13 A 3 flow-t méró kérdés átlaga csak 1 és 6 közötti értéket vehet fel. 


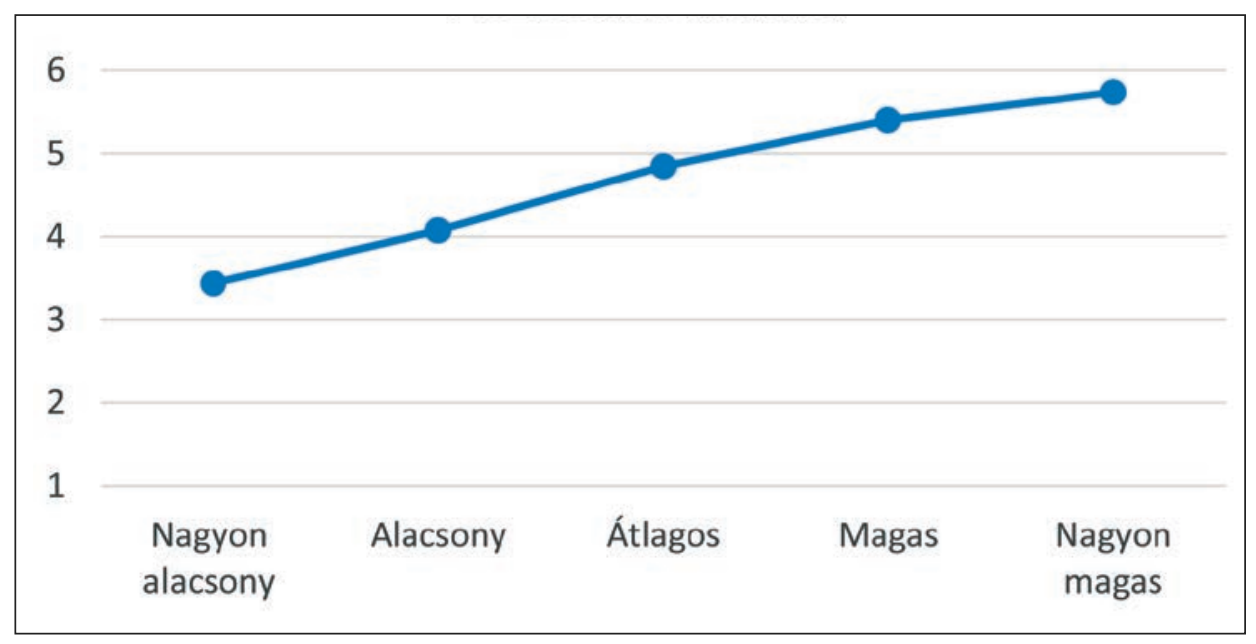

5. ábra. Az Alkotó-végrehajtó hatékonyság skála övezeteinek hatása az I. vizsgálat három flow-t méró tételének átlagos szintjére $(n=1540)$

\section{Megbeszélés}

A tanulmányunkban bemutatott új mérési eljárás, a Mentális Egészség Teszt teoretikus alapja a WHO mentális egészség definíciójával ${ }^{14}$ összhangban álló mentális egészség konstruktum. Ennek értelmében a mentális egészség a globális jóllét olyan foka, amely együtt jár az érzelmi, a pszichológiai, a szociális és a spirituális jól múködéssel, a rezilienciával, a megküzdési és savoring kapacitással, valamint a mentális egészség fenntarthatóságát, a folyamatos fejlődést és a változó feltételekhez való rugalmas alkalmazkodást biztosító kompetenciákkal és személyiség tényezőkkel. Ez a felfogás új elemként azt hangsúlyozza, hogy a mentális egészség mérésénél meg kell haladni azokat az operacionalizálásokat, amelyek ezt a fogalmat a jóllét megfigyelhetó jellemzőivel vagy a mentális zavarok tükör ellentéteként felsorolt jellemzőkkel definiálják.

A cikkünkben ismertetett vizsgálatok (Oláh és mtsai, 2018; Vargha és mtsai, 2019) alapkoncepciója is az volt, hogy a mentális egészségnek több önálló komponense van, amelyek azonban együtt felelősek az egyén lelki

\footnotetext{
14 Mentális egészség: "A jóllét olyan foka, amelyen az egyén reálisan ítéli meg saját képességeit, meg tud küzdeni az élet szokásos stresszeivel, eredményesen és gyümölcsözően képes dolgozni, valamint képes hozzájárulni saját közösségéhez" (Galderisi, Heinz, Kastrup, Beezhold, \& Sartorius 2015, 231. o.).
} 
egészségéért. Számos pszichológiai teszt létezik különböző pozitív pszichológiai konstruktumok mérésére (lásd 3.2. alfejezet), de a vizsgálataink tárgyát képező ötskálás Mentális Egészség Teszt (MET) az első, amelynek modellje egy ötdimenziós komplex struktúrával (jóllét, savoring, alkotó-végrehajtó hatékonyság, önreguláció, reziliencia) próbálja lefedni a mentális egészség széles spektrumát.

A jelen tanulmányban bemutatott vizsgálataink legfontosabb eredménye, hogy két igen nagy, 1000 fó feletti minta segítségével sikerült a MET strukturális és tartalmi validitását igazolni. Feltáró faktoranalízissel azonosítottuk a tesztnek azt a 17 tételét ${ }^{15}$, amellyel elfogadható illeszkedésú ötdimenziós struktúrát kaptunk, s amelyet egy új, független mintán sikerült konfirmatív faktoranalízissel megerósítenünk (lásd 6. táblázat 4. sora). Hozzátesszük, hogy a MET skáláinak belső konzisztenciáját mérő Cronbach- $\alpha$ értékek mindkét vizsgálatban kiválónak tekinthetők (lásd 3. táblázat).

A skálák diszkriminációs validitását többváltozós lineáris regresszió elemzésekkel vizsgálva megállapíthattuk, hogy mind az öt skálának van egy tekintélyes, minimum $44 \%$-ot kitevő olyan egyedi része, amelyet a többi négy skála nem fed le. A legmagasabb, 82,6\%-os egyediségú skála az Önreguláció, de ez az arány a Savoring, az Alkotó-végrehajtó hatékonyság és a Reziliencia skála esetén is meghaladja az 55\%-ot. A Jóllét az egyetlen, amelyet több mint 50\%-ban megmagyaráz a többi skála. Ez arra utal, hogy a mentális egészség összetevői között a jóllét centrális helyet foglal el.

A skálák egyedi jelentésének kibontásához és megerősítéséhez a két vizsgálatban 10 tesztet és emellett több egyedi teszttételt használtunk fel korrelációs elemzésekben. További információkat nyertünk a szociodemográfiai mutatókkal való összefüggések feltárása során. Mindezek alapján az alábbi következtetéseket vonhatjuk le.

A Jóllét skála megbízhatóan méri a vizsgált személy lelki (szubjektív) jóllétét, amely maga is több komponensú (biológiai, pszichológiai, szociális és spirituális). A Jóllét skála igen szoros összefüggést mutat a rokon tesztekkel (Globális Jóllét Kérdőív, PERMA Kérdőív, Diener-féle Virágzás skála, Élettel való elégedettség skála, WHO Jól-Lét Kérdőív), ezért azok parallel tesztjének tekinthető. Fontos eredmény, hogy a Jóllét skála által mért konstruktum szerves része az értelmes célok megléte és a depressziós tünetek hiánya (lásd 7. táblázat). A lelki jóllét összefügg az egyén anyagi helyzetének szubjektív megítélésével, de ez a kapcsolat gyengének mondható. A jóllét jóval erősebb kapcsolatban van a mentális egészség többi összetevőjével.

A Savoring skála azt méri, hogy lelki jóllétének megteremtéséhez a vizsgált személy hogyan képes mentálisan mozgósítani, s ezzel a jelenben újra

15 Az induló 18 tételból mindössze egyet kellett elhagynunk. 
átélni múltbeli pozitív, örömteli emlékeit, élményeit, valamint ezeket jövőbeli tervezett történésekre is kiterjeszteni. Úgy túnik, hogy ez a képesség nőkre minden életkorban jellemzőbb, mint férfiakra (vö. 2. ábra). A validitásvizsgálatok eredményei szerint a Savoring skála szoros kapcsolatban van a mentális egészség minden általunk vizsgált tesztjének (Diener-féle Virágzás skála, Életcél Kérdőív, Globális Jóllét Kérdőív, PERMA Kérdőív, PIK stb.) fő mutatóival, ami megerősíti konstruktumának érvényességét. Speciális jelentésének kibontásához azonban érdemes lenne további vizsgálatokat elvégezni.

Az Alkotó-végrehajtó hatékonyság skála azt méri, hogy az élet szokásosan előforduló nehéz, stresszes, kihívást jelentő helyzeteiben a vizsgált személy hogyan képes különféle kompetenciáit mozgósítva megbirkózni a fellépő nehézségekkel, és a helyzethez igazodó, a problémát megoldó sikeres egyéni, illetve társas viselkedést produkálni.

A kompetencia összetevővel függ össze az is, hogy aki ezen a skálán magas értéket ér el, annak a flow átélő képessége is jobb (lásd 5. ábra), s az ilyen személy az Inkompetencia érzés és a Teljesítmény kudarc kategóriába sorolható maladaptív sémákkal kevéssé jellemezhetó (lásd 9. táblázat).

Az Önreguláció skála arról informál, hogy a személy mennyire képes érzelmeinek, indulatainak, negatív állapotainak szabályozására, kontroll alatt tartására. Ezzel összhangban értelmezhető az Önreguláció skála negatív korrelációja a negatív érzelmi állapotokkal (Ideges vagyok, Feszült vagyok), a PERMA Kérdőív Negatív érzelmek, illetve a Young-féle Séma Kérdőív Elégtelen önkontroll, Negativizmus és Elhagyatottság skálájával (lásd 10. táblázat). Az Önreguláció skálával mért konstruktum valamelyest összefügg az életkorral: idősebb személyeknél az önreguláció néha sikeresebb, mint fiataloknál, s ez a pozitív életkori hatás nőknél markánsabb (lásd 3. ábra).

A Reziliencia skála a lelki ellenálló képesség, a lelki tartalékok szintjét méri, amelyre leginkább akkor van szükség, ha a személy váratlan, lelkileg megterhelő nehézségekkel találja szembe magát. Akinél a reziliencia szintje magasabb, az gyorsabban képes kilábolni egy lelki gödörből, egy hirtelen fellépó, nem várt stresszes szituációból. A 11. táblázat alapján jobb a rezilienciája annak, aki magas szintú megküzdő képességekkel rendelkezik, akinek jó a flow átélő képessége, magas a savoring szintje, tartalmas életcéljai vannak, kevéssé hajlamos a depresszióra és kevéssé jellemezhető különféle, fóleg negativisztikus maladaptív sémákkal. Ahogy az önreguláció, a reziliencia is pozitív kapcsolatban van az életkorral, bár az összefüggés itt gyenge.

A kapott eredmények fontos üzenete, hogy a mentális egészség különböző komponensei mögött olyan kompetenciák állnak, amelyek fejleszthetők, javíthatók, erősíthetők. Legnyilvánvalóbb ez az alkotó-végrehajtó haté- 
konyság esetében, de az életkorral tapasztalható pozitív korreláció alapján erre következtethetünk az önreguláció és a reziliencia esetén is. A savoring kompetencia egy mentális képesség is, ami meditációs technikákkal bizonyára javítható. Önismereti konzultációk, készségjavító foglalkozások, párkapcsolati tréningek, csoportfoglalkozások, súlyosabb esetben viselkedésterápiás intervenciók mind segíthetnek a mentális egészség szintjének növelésében pszichológiailag egészségesnek tekinthető személyek esetében is, amelyek eredményeképpen jelentősen nőhet az átélt szubjektív jóllét, az élettel való elégedettség, köznapi kifejezéssel a boldogság szintje.

Jelen formájában a MET felnőtt személyek vizsgálatára használható, de a tesztnek létezik fiatalabb korosztály esetén alkalmazható változata (Vargha és mtsai, 2019) is. A mindössze 17 tételes, ezért 5-10 perc alatt felvehetó MET segítségével átfogó képet nyerhetünk a vizsgált személy mentális egészségéről a fentebb részletezett öt pillér vonatkozásában. Ha bármelyik skála tekintetében további tisztázandó kérdés merülne fel, célzott fókuszú speciális tesztek (pl. Linton, Dieppe, \& Medina-Lara, 2016) alkalmazását javasoljuk.

A cikkben ismertetett vizsgálatokban ismeretlen személyek online vizsgálattal nyert adataira támaszkodtunk. Az I. vizsgálatban rákérdeztünk a lakhelyre, ami lehetóvé tette a személyek belhoni, illetve külhoni illetékességének megállapítását. Utóbbiak létszáma alacsony $(n=196$, az eredeti teljes minta 11,3\%-a), ezért elhagyásukkal a mintanagyság nem csökkent számottevően. Elhagyásukat leginkább az indokolta, hogy a MET-et a közölt standardjával (vö. 12. táblázat) elsősorban magyarországi használatra alakítottuk ki, ezért el akartuk kerülni, hogy a hazaitól eltérő kultúrkörben élók adatai a hazai teszthasználat megbízhatóságát csökkentsék. Mindamellett nem hallgathatjuk el, hogy a belhoni és a külhoni alminta MET skálaátlaga egyetlen skála esetén sem különbözött egymástól szignifikánsan 5\%-os szinten, továbbá a külhoni mintán külön elvégzett itemanalízisek és CFA eredményei nem voltak gyengébbek, mint a belhoni minta esetében. Ez biztató mindazon vizsgálatok számára (ilyen pl. tanulmányunk II. vizsgálata is), amelyekben lakcím híján nem lehet a belhoni illetékességet megállapítani.

Vizsgálataink korlátaiként kell megemlítenünk a minták online módon való gyújitését, amelyek a nagy elemszámok ellenére sem tekinthetők reprezentatívnak. Emiatt a 12. táblázatban közölt standardokat sem tekinthetjük felhőtlenül megbízhatónak. Az online vizsgálat toborzó technikája nagyban befolyásolja a minta számos adatát, ami például az életkor tekintetében a mi két vizsgálatunkban is megfigyelhető volt (vö. 1. és 2. táblázat). Elemzéseink kizárólag verbális kérdóívek adatain alapulnak, miközben a MET skálái alapján többek között speciális viselkedésekre, mentális múveletekre, attitúdökre stb. következtetünk. Emiatt a skálák validitásának igazolásához nagyon fontos lenne a tapasztalati érvényesség megerősítése is. Például 
hasznos lenne a MET-tel mért mentális egészséget összevetni a fizikális állapotot mérő konkrét adatokkal, vagy szociometriai jellegú kérdőíves tételekkel, amelyek a vizsgált személlyel azonos csoportban tanuló vagy dolgozó más személyektől származnak (vö. 360 fokos vizsgálatok; pl. Mahar \& Strobert, 2010; Nagybányai Nagy, 2006c, 287. o.). A skálák jelentését érdemes lenne továbbá megerősíteni különféle azonosított pszichiátriai diagnózisú klinikai esetek vizsgálatával is.

\section{Irodalom}

Bech, P., Gudex, C., \& Johansen, K.S. (1996). The WHO (Ten) well-being index: validation in diabetes. Psychotherapy and Psychosomatics, 65(4), 183-190.

Beck, A.T., Guth, D., Steer, R. A., \& Ball, R. (1997). Screening for major depression disorders in medical inpatients with the Beck Depression Inventory for primary care. Behaviour Research and Therapy, 35, 785-791.

Block, J., \& Kremen, A.M. (1996). IQ and ego-resiliency: conceptual and empirical connections and separateness. Journal of Personality and Social Psychology, 70(2), 349-371.

Bryant, F.B, \& Veroff, J. (2007). Savoring: A new model of positive experience. Mahwah, NJ: Lawrence Erlbaum Associates Publishers

Butler, J., \& Kern, M.L. (2016). The PERMA-Profiler: A brief multidimensional measure of flourishing. International Journal of Wellbeing, 6(3), 1-48.

Campbell-Sills, L., \& Stein, M. (2007). Psychometric analysis and refinement of the ConnorDavidson Resilience Scale (CD-RISC): Validation of a 10-item measure of resilience. Journal of Traumatic Stress, 20(6), 1019-1028.

Cohen, J. (1988). Statistical power analysis for the behavioral sciences. 2nd Edition. Hillsdale: Lawrence Erlbaum.

Connor, K.M., \& Davidson, J.R. (2003). Development of a new resilience scale: The ConnorDavidson Resilience Scale (CD-RISC). Depression and Anxiety, 18(2), 76-82.

Crumbaugh, J.C., \& Maholick, L.T. (1964). An experimental study in existentialism: The psychometric approach to Frankl's concept of noogenic neurosis. Journal of Clinical Psychology, 20(2), 200-207.

DeVellis, R.F. (2016). Scale development: Theory and applications (Vol. 26). 4th Edition. Thousand Oaks, CA: Sage Publications

Diener, E.D., Emmons, R.A., Larsen, R.J., \& Griffin, S. (1985). The satisfaction with life scale. Journal of Personality Assessment, 49(1), 71-75.

Diener, E., Wirtz, D., Tov, W., Kim-Prieto, C., Choi, D., Oishi, S., et al. (2009). New measures of well-being: Flourishing and positive and negative feelings. Social Indicators Research, $39,247-266$.

Fredrickson, B. (2009). Positivity: Top-notch research reveals the 3-to-1 ratio that will change your life. New York: Crown

Galderisi, S., Heinz, A., Kastrup, M., Beezhold, J., \& Sartorius, N. (2015). Toward a new definition of mental health. World Psychiatry, 14(2), 231.

Hattori, M., Zhang, G., \& Preacher, K.J. (2017). Multiple local solutions and geomin rotation. Multivariate Behavioral Research, 52(6), 720-731.

Huppert, F., \& So, T.C. (2013). Flourishing across Europe: Application of a new conceptual framework for defining well-being. Social Indicators Research, 110, 837-861. 
Kasser, T. \& Ryan, R.M. (1996). Further examining the American dream: Differential correlates of intrinsic and extrinsic goals. Personality and Social Psychology Bulletin, 22(3): 280-287.

Konkolÿ Thege, B., \& Martos, T. (2006). Az Életcél Kérdőív magyar változatának jellemzői. Mentálhigiéné és Pszichoszomatika, 7, 153-170.

Linton, M.J., Dieppe, P., \& Medina-Lara, A. (2016). Review of 99 self-report measures for assessing wellbeing in adults: exploring dimensions of well-being and developments over time. BMJ Open 2016;6:e010641. doi:10.1136/bmjopen-2015-010641

Lyubomirsky, S. (2008). Hogyan legyünk boldogok? Életünk átalakitásának útjai tudományos megközelitésben. Budapest: Ursus Libris Bt.

Mahar, J. A., \& Strobert, B. (2010). The use of 360-degree feedback compared to traditional evaluative feedback for the professional growth of teachers in K-12 education. Planning and Changing, 41, 147-160.

Martos, T., Sallay, V., Désfalvi, J., Szabó, T., \& Ittzés, A. (2014). Az Élettel való Elégedettség Skála magyar változatának (SWLS-H) pszichometriai jellemzői= Psychometric characteristics of the Hungarian version of the Satisfaction with Life Scale (SWLS-H). Mentálhigiéné és Pszichoszomatika, 15(3), 289-303.

Martos, T., Szabó, G., \& Rózsa, S. (2006). Az Aspirációs Index rövidített változatának pszichometriai jellemzői hazai mintán. Mentálhigiéné és Pszichoszomatika, 7, 171-191.

Maydeu-Olivares, A. (2017). Maximum likelihood estimation of structural equation models for continuous data: Standard errors and goodness of fit. Structural Equation Modeling: A Multidisciplinary Journal, 24(3), 383-394.

Muthén, L.K., \& Muthén, B.O. (1998-2011). Mplus User's Guide. Sixth Edition. Los Angeles CA: Muthén \& Muthén

Nagy, H., Magyaródi, T., Oláh, A., \& Vargha, A. (2019): A Rövidített Savoring Hit Kérdőív kifejlesztése és pszichometriai elemzése. In E. Lippai (szerk.), Összetart a sokszínúség. A Magyar Pszichológiai Társaság XXVIII. Országos Tudományos Nagygyúlésének kivonatkötete (138). Debrecen: Magyar Pszichológiai Társaság

Nagybányai Nagy, O. (2006a). A pszichológiai tesztek reliabilitása. In: S. Rózsa, O. Nagybányai Nagy, \& A. Oláh (szerk.), A pszichológiai mérés alapjai (103-115). Budapest: Bölcsész Konzorcium

Nagybányai Nagy, O. (2006b). A pszichológiai tesztek validitása. In S. Rózsa, O. Nagybányai Nagy, \& A. Oláh (szerk.), A pszichológiai mérés alapjai (117-124). Budapest: Bölcsész Konzorcium

Nagybányai Nagy, O. (2006c). Tesztek a munka világában: a nem klinikai tesztalkalmazások. In: S. Rózsa, O. Nagybányai Nagy, \& A. Oláh (szerk.), A pszichológiai mérés alapjai (276-289). Budapest: Bölcsész Konzorcium

Oláh, A. (2005a). Érzelmek, megküzdés és optimális élmény. Budapest: Trefort Kiadó

Oláh, A. (2005b). Anxiety, coping and flow. Empirical studies in interactional perspective. Budapest: Trefort Press

Oláh, A. (2016). A new model and a new inventory of well-being, Complete Abstract Book - per theme - per type of Session of the 8th European Conference on Positive Psychology (55). Angers-France. June 28th-July 1st. 2016.

Oláh, A., \& Kapitány-Fövény, M. (2012): A pozitív pszichológia tíz éve. Magyar Pszichológiai Szemle, 67(1), 19-45.

Oláh, A., Nagy, H., Magyaródi, T., Török, R., \& Vargha, A. (2018). Egy új mentális egészséget méró kérdőív, a MET kidolgozása. In: E. Lippai (szerk.), Változás az állandóságban. A Magyar Pszichológiai Társaság XXVII. Országos Tudományos Nagygyúlése. Kivonatkötet (80-81). Budapest: Magyar Pszichológiai Társaság 
Oláh, A., Vargha, A., Csengődi, M., Bagdi, B., \& Diósi, T. (2020). Magyarország Boldogságtérképe. http:/ / boldogsagprogram.hu/magyarorszag-boldogsagterkepe-2020/

Rózsa, S., Szádóczky, E., \& Füredi, J. (2001). A Beck Depresszió Kérdőív rövidített változatának jellemzói hazai mintán. Psychiatria Hungarica, 16, 384-402.

Ryff, C.D., \& Marshall, W.V. (Ed.). (1999). The self and society in aging processes. New York, NY: Spring Publishing Company, Inc.

Seligman, M. (2018). PERMA and the building blocks of well-being. Journal of Positive Psychology, 13(4), 333-335.

Smith, B.W., Dalen, J., Wiggins, K., Tooley, E., Christopher, P., \& Bernard, J. (2008): The Brief Resilience Scale: Assessing the ability to bounce back. International Journal of Behavioral Medicine, 15, 194-200.

Southwick, S.M., \& Charney, D.S. (2018). Resilience: The science of mastering life's greatest challenges. New York: Cambridge University Press

Susánszky, É., Konkolÿ Thege, B., Stauder, A., \& Kopp, M. (2006) A WHO Jól-Lét Kérdőív rövidített (WBI-5) magyar változatának validálása a HungaroStudy 2002 országos lakossági egészségfelmérés alapján. Mentálhigiéné és Pszichoszomatika, 7, 247-255.

Szondy, M., Martos, T., Szabó-Bartha, A., \& Pünkösty, M. (2014). A Rövidített Pozitív Élmények Feldolgozási Módjai Skála magyar változatának reliabilitás-és validitásvizsgálata. Mentálhigiéné és Pszichoszomatika, 15(3), 305-316.

Unoka, Zs., Rózsa, S., Fábián, Á., Mervó, B., \& Simon, L. (2004). A Young-féle Séma Kérdőív: A korai maladaptív sémák jelenlétét mérő eszköz pszichometriai jellemzőinek vizsgálata. Psychiatria Hungarica, 19(3), 235-243.

Vargha, A. (2004). A kétszempontos sztochasztikus összehasonlítás modellje. Statisztikai Szemle, 82(1), 67-82.

Vargha, A. (2016). A ROPstat statisztikai programcsomag. Statisztikai Szemle, 94(11-12), 1165-1192.

Vargha, A. (2019). Többváltozós statisztika dióhéjban: változó-orientált módszerek. Budapest: Pólya Kiadó

Vargha, A., Török, R., Diósi, K., \& Oláh, A. (2019). Boldogságmérés az iskolában. Magyar Pszichológiai Szemle, 74(3-4), 327-346.

Windle, G., Bennett, K.M. \& Noyes, J. (2011). A methodological review of resilience measurement scales. Health and Quality of Life Outcomes, 9:8. Doi: 10.1186/1477-7525-9-8.

\section{Köszönetnyilvánítás}

A cikkben említett kutatásokat a Károli Gáspár Református Egyetem (20643B800/2018 számú kutatói pályázat) és az NKFI támogatta (NKFI-6, 116965 számú pályázat). A szerzők ezúttal mondanak köszönetet a kézirat ismeretlen lektorainak és a folyóirat felelős szerkesztőjének számtalan értékes megjegyzéséért és javaslatáért, amelyek nagyban segítették a cikk végső változatának megformálását.

\section{A szerzók munkamegosztása}

A MET alapkoncepciójának kidolgozása és a cikk elméleti részének megírása az első és az utolsó szerző munkája. Ez utóbbi nevéhez köthető az I. vizsgálat lebonyolítása is. A második szerzőnek köszönhető a II. vizsgálat lebonyolítása. Az összes statisztikai elemzés 
végrehajtása és az eredmények leírása az első szerző nevéhez kötődik. A harmadik szerző nevéhez köthető a MET-tel kapcsolatban számos korábbi adatgyújtés menedzselése. A kéziratot mind a négy szerző alaposan átolvasta és aktívan hozzájárult a végső változat létrejöttéhez.

\section{Nyilatkozat}

A szerzők ezúton nyilatkoznak, hogy a jelen tanulmánnyal, illetve a tanulmányban ismertetett vizsgálatokkal kapcsolatban érdekütközésről nem tudnak.

\section{FÜGGELÉK}

\section{Mentális Egészség Teszt (MET)}

Az alábbi állítások az emberek általános életérzését, jellemző tulajdonságait és életfelfogását írják le. Nincsenek jó vagy rossz válaszok. Kérem, legyen olyan őszinte, amennyire csak tud és jelezze minden tételnél a megfeleló szám bekarikázásával, hogy milyen mértékben jellemző Önre az állítás!

\begin{tabular}{|l|c|c|c|c|c|c|}
\hline & $\begin{array}{c}\text { egyáltalán } \\
\text { nem } \\
\text { jellemzó }\end{array}$ & $\begin{array}{c}\text { nem } \\
\text { jellem- } \\
\text { zó }\end{array}$ & $\begin{array}{c}\text { kicsit } \\
\text { jellem- } \\
\text { zó }\end{array}$ & $\begin{array}{c}\text { jel- } \\
\text { lemzó }\end{array}$ & $\begin{array}{c}\text { nagyon } \\
\text { jellem- } \\
\text { zó }\end{array}$ & $\begin{array}{c}\text { teljes } \\
\text { mértékben } \\
\text { jellemzó }\end{array}$ \\
\hline $\begin{array}{l}\text { 1. Mindennapjaimban } \\
\text { érezhetően több az öröm, } \\
\text { mint a bánat./J }\end{array}$ & 1 & 2 & 3 & 4 & 5 & 6 \\
\hline $\begin{array}{l}\text { 2. Könnyen válok } \\
\text { türelmetlenné./Ö }\end{array}$ & 1 & 2 & 3 & 4 & 5 & 6 \\
\hline $\begin{array}{l}\text { 3. Könnyen fel tudom } \\
\text { eleveníteni a múlt kellemes } \\
\text { emlékeinek örömét./S }\end{array}$ & 1 & 2 & 3 & 4 & 5 & 6 \\
\hline $\begin{array}{l}\text { 4. Nehéz idók után hamar } \\
\text { magamhoz térek./R }\end{array}$ & 1 & 2 & 3 & 4 & 5 & 6 \\
\hline $\begin{array}{l}\text { 5. Gyakran vannak olyan } \\
\text { ötleteim, amelyekhez mások } \\
\text { eredményesen tudnak } \\
\text { kapcsolódni és továbbgondol- } \\
\text { kodásra készteti óket./AV }\end{array}$ & 1 & 2 & 3 & 4 & 5 & 6 \\
\hline $\begin{array}{l}\text { 6. A stresszes eseményeket } \\
\text { nehezen viselem./R- }\end{array}$ & 1 & 2 & 3 & 4 & 5 & 6 \\
\hline $\begin{array}{l}\text { 7. Mások szerint is jó } \\
\text { problémamegoldó vagyok./AV }\end{array}$ & 1 & 2 & 3 & 4 & 5 & 6 \\
\hline $\begin{array}{l}\text { 8. Hirtelen természetú vagyok } \\
\text { (elóbb cselekszem, utána } \\
\text { gondolkodom)./Ö- }\end{array}$ & 1 & 2 & 3 & 4 & 5 & 6 \\
\hline
\end{tabular}




\begin{tabular}{|c|c|c|c|c|c|c|}
\hline & $\begin{array}{c}\text { egyáltalán } \\
\text { nem } \\
\text { jellemzó }\end{array}$ & $\begin{array}{l}\text { nem } \\
\text { jellem- } \\
\text { zó }\end{array}$ & $\begin{array}{l}\text { kicsit } \\
\text { jellem- } \\
\text { zó }\end{array}$ & $\begin{array}{c}\text { jel- } \\
\text { lemzó }\end{array}$ & $\begin{array}{l}\text { nagyon } \\
\text { jellem- } \\
\text { zó }\end{array}$ & $\begin{array}{c}\text { teljes } \\
\text { mértékben } \\
\text { jellemzö }\end{array}$ \\
\hline $\begin{array}{l}\text { 9. Sikeresen el tudom érni a } \\
\text { magam elé kitúzött célokat./ } \\
\text { AV }\end{array}$ & 1 & 2 & 3 & 4 & 5 & 6 \\
\hline $\begin{array}{l}\text { 10. Szeretem elraktározni az } \\
\text { átélt örömteli idők emlékét, } \\
\text { hogy később felidézhessem } \\
\text { őket./S }\end{array}$ & 1 & 2 & 3 & 4 & 5 & 6 \\
\hline $\begin{array}{l}\text { 11. A lelki megrázkódtatások } \\
\text { után elég gyorsan felépülök./R }\end{array}$ & 1 & 2 & 3 & 4 & 5 & 6 \\
\hline $\begin{array}{l}\text { 12. Jó kedvre tudom hangolni } \\
\text { magam, ha elképzelem, milyen } \\
\text { lesz egy közelgő boldog idő./S }\end{array}$ & 1 & 2 & 3 & 4 & 5 & 6 \\
\hline $\begin{array}{l}\text { 13. Rendszerint eltart egy ideig, } \\
\text { amíg továbblépek életem egy- } \\
\text { egy nehéz pillanatán./ R- }\end{array}$ & 1 & 2 & 3 & 4 & 5 & 6 \\
\hline $\begin{array}{l}\text { 14. Lelki állapotom jónak } \\
\text { mondható./J }\end{array}$ & 1 & 2 & 3 & 4 & 5 & 6 \\
\hline $\begin{array}{l}\text { 15. Jó vagyok az olyan } \\
\text { munkákban, ahol új és eredeti } \\
\text { ötletek kellenek./AV }\end{array}$ & 1 & 2 & 3 & 4 & 5 & 6 \\
\hline $\begin{array}{l}\text { 16. Ideges leszek, ha valami } \\
\text { nem úgy alakul, ahogy } \\
\text { terveztem./Ö- }\end{array}$ & 1 & 2 & 3 & 4 & 5 & 6 \\
\hline $\begin{array}{l}\text { 17. Gyakran jók a megsejtéseim } \\
\text { arról, hogy hogyan } \\
\text { gondolkoznak és éreznek az } \\
\text { emberek./ AV }\end{array}$ & 1 & 2 & 3 & 4 & 5 & 6 \\
\hline $\begin{array}{l}\text { 18. Mindent összevetve } \\
\text { mennyire mondaná magát } \\
\text { boldognak ( } 1 \text { : nagyon nem, } 6 \text { : } \\
\text { nagyon igen)? / J ....... }\end{array}$ & & & & & & \\
\hline
\end{tabular}

Jelölés: J = Jóllét; Ö = Önreguláció; $\mathrm{S}$ = Savoring; $\mathrm{R}$ = Reziliencia; AV = Alkotó-végrehajtó hatékonyság. A skálajel utáni mínusz (-) jel a tétel átfordítandó voltát jelzi.

Skálaképzési útmutató (javitott, a 6. tételt kihagyó végleges változat):

Jóllét (J): 1., 14. és 18. tételek pontszámainak átlaga

Savoring (S): 3., 10. és 12. tételek pontszámainak átlaga

Alkotó-végrehajtó hatékonyság (AV): 5., 7., 9., 15. és 17. tételek pontszámainak átlaga

Önreguláció (Ö): 2., 8. és 16. tételek pontszámainak átlaga, miután mind a három tételt átfordítottuk a 7-x transzformációval ( $x$ az eredeti, 7-x az átfordított pontszám)

Reziliencia (R): 4., 11. és 13. tételek pontszámainak átlaga, miután a 13. sorszámú tételt átfordítottuk a 7-x transzformációval (x az eredeti, 7-x az átfordított pontszám) 


\title{
Measuring well-being and mental health: the mental health test
}

\author{
VARGHA, ANDRÁS - ZÁBÓ, VIRÁG - \\ TÖRÖK, REGINA - OLÁH, ATTILA
}

Theoretical background: Beyond that mental health is related to biological, psychological, social, and spiritual well-being, it is a capacity to maintain and experience the positive conditions with effective coping, savoring, resilience and dynamic self-regulation skills. One of the most important responsibility of positive psychology is to construct scales measuring mental health. Aim: the purpose of this study is to present the psychometric characteristics of the new version of the Mental Health Test (MHT) based on five pillars. Method: Two online cross-sectional studies with self-report questionnaires. Study I: 1540 persons (391 men, 1149 women; mean age 52.0 years, SD = 11.3 years) filled in MHT, PERMA Profiler, Global Health, Diener's Flourishing Scale, Shortened Savoring and Shortened Psychological Immune Competence questionnaires along with questions about physical and psychological well-being and demographic data. Study II: 1083 persons (233 men, 847 women; mean age 33.9 years, $\mathrm{SD}=12.2$ years) filled in MHT, Aspiration Index, Shortened Beck Depression Inventory, WHO Well-Being Scale, Satisfaction with Life Scale, Purpose in Life Test, and Shortened Young Maladaptive Schema Questionnaire, along with questions about demographic data, religiosity, physical and mental health. Results: In Study I exploratory factor analysis identified the five-factor structure of MHT with 17 items, having also good fit measures in confirmative factor analysis. In Study II the five-factor model of the five subscales yielded excellent fit measures in confirmatory factor analysis $(\mathrm{RMSEA}=.051, \mathrm{pClose}=.408, \mathrm{CFI}=.950, \mathrm{TLI}=.936)$. In both studies, Cronbach's $\alpha$ values of the five subscales (all above 0.70 ) indicated a high level of internal consistency. The discriminant validity is proven by the fact that each subscale had a minimum $44 \%$ part not covered by the set of other subscales. The content validity of the subscales was confirmed by ten tests about mental health, some special questions and socio-demographic indicators. Subscale of well-being showed a definite positive correlation with financial background. Creative and executing efficiency correlated with flow and education. We found also a positive correlation of self-regulation and resilience subscales with age, and women showed a higher level of savoring than men at all age levels. Conclusion: MHT can be considered a reliable and valid measurement tool for well-being, savoring, creative and executing efficiency, self-regulation and resilience dimensions of mental health.

Keywords: happiness, subjective well-being, mental health, Mental Health Test, MHT

A cikk a Creative Commons Attribution 4.0 International License (https:/ / creativecommons.org/ licenses/by/4.0/) feltételei szerint publikált Open Access közlemény, melynek szellemében a cikk bármilyen médiumban szabadon felhasználható, megosztható és újraközölhető, feltéve, hogy az eredeti szerző és a közlés helye, illetve a CC License linkje és az esetlegesen végrehajtott módosítások feltüntetésre kerülnek. (SID_1) 